\title{
Orality, Fluid Textualization and Interweaving Themes. Some Remarks on the Doloneia: Magical Horses from Night to Light and Death to Life
}

\author{
Anton Bierl ${ }^{*}$
}

\section{Introduction: Methodological Reflection}

The Doloneia, Book 10 of the Iliad, takes place during the night and its events have been long interpreted as unheroic exploits of ambush and cunning. First the desperate Greek leader Agamemnon cannot sleep and initiates a long series of wake-up calls as he seeks new information and counsel. When the Greeks finally send out Odysseus and Diomedes, the two heroes encounter the Trojan Dolon who intends to spy on the Achaeans. They hunt him down, and in his fear of death, Dolon betrays the whereabouts of Rhesus and his Thracian troops who have arrived on scene late. Accordingly, the focus shifts from the endeavor to obtain new knowledge to the massacre of enemies and the retrieval of wondrous horses through trickery and violence.

* I would like to thank Antonios Rengakos for his kind invitation to Thessaloniki, as well as the editors of this volume, Franco Montanari, Antonios Rengakos and Christos Tsagalis. Besides the Conference Homer in the 21st Century, I gave other versions of the paper at Brown (2010) and Columbia University (CAM, 2011). I am grateful to the audiences for much useful criticism, particularly to Casey Dué, Deborah Boedeker, Marco Fantuzzi, Pura Nieto Hernandez, David Konstan, Kurt Raaflaub and William Harris for stimulating conversations. Only after the final submission of this contribution, Donald E. Lavigne granted me insight into his not yet published manuscript "Bad Kharma: A 'Fragment' of the Iliad and Iambic Laughter" in which he detects iambic resonances in the Doloneia, and I received a reference to M.F. Williams, "Crossing into Enemy Lines: Military Intelligence in Iliad 10 and 24," Electronic Antiquity 5.3 (Nov. 2000) who confirms the parallels between Iliad 10 and 24 from a military perspective. 
Iliad 10 is a perfect test case to reflect on methods and methodology in Homeric research. Besides rare exceptions, ${ }^{1}$ the Doloneia is unanimously regarded as not belonging to the Iliad or to Homer. ${ }^{2}$ However, with respect to early Greek scholarship, we only have the scholium to Book 10, line 1 which might support this view. All of the manuscripts, on the other hand, contain the Doloneia, which - as a result - is always included in modern editions of the Iliad. Because it is part of the later twenty-four Books, it would have been a serious question to exclude one Book from the perfect totality. ${ }^{3}$ However, since the heyday of analytical philology in the 19th century, modern critics have been keen to define it as a single song, an accretion stemming from a later Bearbeiter, and not identical with Homer, the original composer. ${ }^{4}$ As is well known, analysis aims at dissolving and sorting out the later strata from the genuine poem. Since each critic assessed different Homeric passages as authentic, it became soon clear that such an analytical criticism of discrepancies and inconsistencies depended on modern aesthetic judgments.

Greek philology strove to be as scientific as natural science, but in the end Homer and the epics were disparaged. The counter-reaction to analysis was Unitarianism. Adherents to this view wanted to preserve Homer as one single poet, the first and best poet of Western civilization who composed everything following a carefully constructed plan. Literacy, the invention and adoption of the alphabet, was the precondition for this approach, which many scholars have been pursuing until

1 Shewan 1911; van Leeuwen 1912, esp. 341 ad Il.10.1 ff. Older literature esp. Bäumlein 1856, 425-426; Gladstone 1858, 389-392, German: Gladstone 1863, 431-433; titles cited in Ameis/Hentze 1888, 15; Shewan 1911, $13-$ 14. Recent: Schnapp-Gourbeillon 1981, 104-131, esp. 104-107; SchnappGourbeillon 1982, 53-74; Cirio 1998; Alden 2000, 143-149, esp. 144; Cirio 2003. See now the detailed monograph, with edition and commentary by Dué/Ebbott 2010.

2 Older secondary literature in Ameis/Hentze 1888, 4-16; esp. Ranke 1881; Wilamowitz 1920, 60-67, 515; Schadewaldt 1938, 142 n. 4; Klingner 1940; Von der Mühll 1952 4, 182-187; West 2001, 10-11; 2011, 233-235; more differentiated: Reinhardt 1961, 243-250; Fenik 1964; Danek 1988; Hainsworth 1993, 151-155. See also the survey by Cirio 1998, 11-13.

3 Schnapp-Gourbeillon 1981, 105 n. 11 who is asking herself where to end the cutting.

4 Wilamowitz 1920, 60-67, 515; Von der Mühll 1952, 4, 182-187. See the overview of older literature by Shewan 1911, 14-16. 
today. ${ }^{5}$ While Unitarianism shrank away from the athetizing frenzy of the 19th and early 20th centuries, it soon came back to judge Iliad 10 as a later addition not belonging to Homer. ${ }^{6}$ A late and modern exception was Alexander Shewan's vehement defense in 1911. ${ }^{7}$ Most unitarians developed their position without taking notice of Milman Parry and Albert Lord. ${ }^{8}$ A different position was taken by the cautious movement of neo-unitarians like Wolfgang Schadewaldt and Karl Reinhardt, who believed in a more flexible development of the composition process. Yet still, the Doloneia was excluded as non-Homeric, even though Reinhardt and Friedrich Klingner initiated the appreciation of its art. ${ }^{9}$ Even today, in the view of many scholars, such an artist seems to be too modern and later than Homer. Followers of the oral poetry theory in its strict sense, on the other side, with their insight that Greek epic is based on composition in performance, must believe that everything is tradition. ${ }^{10}$ The theory of dictation even led many to believe that in the case of the Doloneia we still have a later song inserted into the Homeric tradition. Moreover, with its focus on composition, on verseunits, and formulas, research into oral poetry soon became an arcane discipline that again was less interested in the big picture. Albert Lord, one of the founding fathers, was an exception in this respect because he also examined typical scenes, themes, large patterns, and multiforms. In doing so, he made valuable observations on the Doloneia and suggested that it is part of the tradition, perhaps an alternative to Book 9, which had been attacked by analysts as well. ${ }^{11}$ Neoanalysis, on the contrary, adopted the premises of Unitarianism. In this respect, scholars wanted to show that Homer used written texts of the Epic Cycle by referring to and citing from them in his composition.

5 Among others, Latacz 1996 tries to combine oral poetry with Unitarianism; according to this view, orality is important for the pre-history of Homer; however, the monumental poems can be explained only by an ingenuous poet, the "first poet of the West" (15) and "the founder of Western textuality" (17); see 15-21; thus, orality is restricted to pre-Homeric traditions.

6 See Schadewaldt 1938, 142 n. 4 and Reinhardt 1961, 243-250.

7 Shewan 1911 and early unitarians, esp. Bäumlein 1856, 425-426; Gladstone 1858, 389-392, in German: Gladstone 1863, 431-433 and other names listed in Ameis/Hentze 1888, 15.

8 E.g. Parry 1928; Parry 1930; Lord 1960; Lord 1991; Lord 1995.

9 Reinhardt 1961, 243-250; Klingner 1940.

10 See now Dué/Ebbott 2010.

11 Lord 1960, 186-197, esp. 194; for the alternative, see already Klingner 1940, 363, among others. 
Since the 1980s, new trends in orality have focused less on composition and more on the audience's reception. Scholars have realized that oral discourse is the usual, unmarked case, while written language, on the contrary, is the special, marked case. Furthermore, traditional referentiality has helped critics to look at larger narrative patterns and how signs include entire stories. Moreover, speech-act theory, discourseanalysis and intercultural comparison have contributed so that further progress has been made. ${ }^{12}$ Last not least, Gregory Nagy, who has shaped a highly original theory of an evolutionary Homer, has refined Albert Lord's insights on oral multiforms. According to Nagy, the Iliad and Odyssey emerged only gradually in a long historical process, reaching from a dark Mycenaean past, over the Sattelzeit of the 9th and 8th to the 6th and 5th centuries BC. Beyond this, we must reckon with further development through the age of Aristarchus. It is attested that Hipparchus regulated the agon of the Panathenaea: in the famous competition, the two monumental poems of Panhellenic status had to be performed at full length in alternation, with one rhapsode following the

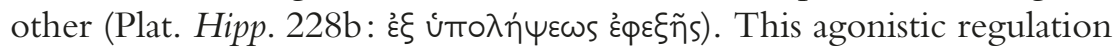
had a significant impact on the evolution of the text. Thus, the oral tradition could be transformed into a continuous and elaborate narrative that was then, in the age of writing, transmitted as a text in the form of a script. Hence our 'Homer' is a snapshot of a historical moment as well as a reprojected, biographic construct. ${ }^{13}$ By means of ongoing extensions, the plot is built on much shorter songs stitched together on the principle of variation and combination. ${ }^{14}$ From completely different unitarian angles, and to some extent in the vein of his teacher Reinhardt, Uvo Hölscher applied research on folklore to show how Homeric epics evolved from a hypothetical Urform, the short "simple story", which was extended to its monumental size under Panhellenic conditions. ${ }^{15}$ Recently, Neoanalysis and orality have been fruitfully

12 Foley 1990; Foley 1995; Foley 1999; Bakker 1996; Bakker 2005.

13 Nagy 1996; Nagy 1996a; Nagy 2002; Nagy 2003; Nagy 2008/09; Nagy 2009/ 10; Bierl 2010; Bierl 2011; Frame 2009, 515-647.

14 See Bierl 2010. Nagy's evolutionary view is, on the one hand, not too far away from analytical positions, such as e.g. Von der Mühll 1952, with his emphasis on the importance of the Peisistratean redaction and on the formative period around $600 \mathrm{BC}$; ibid. 2, 7-10, 182-183. But analysts, on the other hand, believe in texts and in Homer, and want to separate Homer from later layers. In this respect, more flexible is Reinhardt 1961 as a neo-unitarian evolutionist.

15 Hölscher 1988, esp. 25-34, 162-169. 
combined, thus dissolving the strict lines separating the different schools. ${ }^{16}$

In order to make further progress, we have to use a holistic point of view that integrates different approaches in innovative ways. It is time to supersede the old divide between entrenched positions and to make fruitful use of recent trends, such as orality, traditional referentiality, the evolutionary and the multiform model. In the age of the "death of the author" ${ }^{" 17}$ it is easier to cope with the insight that the decisive factor is not so much Homer as an individual poet but the tradition that expands and evolves under different conditions to a continuous and consistent poem. Thus, we can abandon the model that the Doloneia, because of its specific features, was composed at a later stage and then inserted into the Iliad, or that its contemporary poet, familiar with the traditional art, tried to emulate the tradition shortly after the Iliad in order to display his talent against it. ${ }^{18}$ Rather, it becomes clear by now that the Doloneia is also part of the vast tradition that gradually evolves into a monumental and homogenous song through expansion, variation and integration of other songs. This development results from a shift of place, context and performance practice. Whereas in the beginning, rather short epic songs were sung at aristocratic courts in Asia Minor, later, epic traditions of greater extent were performed in larger venues and in new agonistic and Panhellenic contexts. Accordingly, the setting moved to large festivals, from the Panionia celebrated in Asia Minor in the 9th and 8th centuries to the Athenian Panathenaea at the end of the 6th century BC. ${ }^{19}$

16 Burgess 2006 is particularly interesting, since he combines orality, audience reception, motif transference, and the level of myth.

17 Barthes 1977. For the metaphor of the hypertext with regard to Iliad 10, see now Dué 2010 with reference to further scholarship.

18 Danek 1988, 48-49, 230-234; Hainsworth 1993, 155.

19 For the Panionia, see Frame 2009, 515-647. The evolutionary approach is mostly compatible with studies in Ancient History, as for example by Raaflaub, who emphasizes the archaic, contemporary setting against the view that historical events of Bronze Age history can be preserved through the medium of hexameter poetry. See Raaflaub 2003; Raaflaub 2005; Raaflaub 2006. 


\section{The Doloneia and Its Poetics}

In this contribution, I position myself within Nagy's model of an ongoing and gradual process of textualization. Since Georg Danek (1988) has shown that the linguistic formulaic material of the Doloneia is deeply rooted in tradition, according to such a methodology, we cannot possibly decide what is later and what is earlier, or what is genuine and what is a late imitation. Everything is part of tradition and therefore authentic. In the multiform patterning of textualization and in the gradual process of weeding out the discrepancies, the narrative becomes an organic entity that can easily be confounded with a personal composition of an ingenious author. Casey Dué and Mary Ebbott (2010) depart from the same premises and have laid the ground for the following considerations with their recent monograph.

As I have noted above, I want to widen my spectrum of approaches and combine this view with Hölscher's new, evolutionary Neo-Unitarianism, with Jonathan Burgess' new Neoanalysis, particularly with a fresh glance at myth, ritual, and folklore patterns, symbolic and traditional imagery, diachronic shifting, narrativity, and audience reception. It is important to understand how myth, the Epic Cycle and Homeric epics interact, and how myth is transformed into the complex narrative line of the plot. In this paper, I will focus on the following questions: 1) what is the narrative function of the Doloneia; 2) what effect does it have on the audience; 3) what are its symbolic underpinnings; and 4) what would we miss if the Doloneia were excluded. Moreover, I want to investigate the narrative and symbolic lines that connect the Doloneia with the rest of the Iliad. This issue ties in with the question of how key motifs are interwoven, transferred from myth and other media, and in what way they are patterned.

Critics have almost unanimously rejected this song as spurious. Inferring from the correct observation that Iliad 10 is very different from the rest of the poem, they consider it anti-heroic, almost burlesque, brutal, violent, chaotic, strange, inferior, poorly motivated, and simple. In his commentary, for example, Walter Leaf characterizes singularities of the opening lines as follows: "inappropriateness of the lines" (ad Il. 10.1), "so confused as to be practically unintelligible", "singularly pointless", "turgid and tasteless" (ad 10.5), "too strange" (ad 10.7), "incompetent" (ad 10.8). ${ }^{20}$ As do many analysts, Leaf applies his

20 Leaf 1900, 426-427. 
own aesthetic criteria to a text that obviously does not belong to our aesthetic system of naturalistic storytelling. ${ }^{21}$ Defenders, on the other hand, claim that this is an example of great poetry. ${ }^{22}$ In a literary case built on circumstantial evidence, Shewan, the most forceful of the defenders, tries to refute any alleged deficiency once more on aesthetic grounds deeply rooted in early 20 th century literary taste. ${ }^{23}$

Dué and Ebbott, with good reason, explain the linguistic and stylistic differences of the passage with a different subgenre of narrative, that is, with the ambush, lokhos. ${ }^{24}$ I would add that the Doloneia is based on a poetics of night, death, atavism, the 'Other', the anti-heroic, hunting, and spying as well. Moreover, it draws on typical features of a katabasis and of a quest for hidden magical powers. Thus, I contend that Iliad 10 is built upon myth, ritual and folktale patterns and motifs.

The myth of Rhesus is known from the scholia. As Bernard Fenik has demonstrated, these versions that have found access into the Cycle are incorporated into the Iliad in a completely different way. ${ }^{25}$ Only a few traits are maintained, that is, the main mythic element. As for the rest of the story, the oracle or the great one-day battle success of the latecomer (in the Pindaric version) would diminish the role of Hector too much (schol. ad Il. 10.435, Townley [= T], Venetus A and B [= A, B]). ${ }^{26}$ Through this example, one can study how mythic traditions interact with the Homeric tradition and how both refer to each other in an oral way. The oracle version (schol. ad Il. 10.435 A) focuses especially on the wonder motif. The prophecy predicts that Rhesus would be invincible if he and his horses had tasted the waters of the river Scamander. Just as the audience knows about the myth, so the Homeric tra-

21 Ameis/Hentze 1888, 3-16 introduction: e.g. "Mängel”, "große Unklarheit in der inneren Entwicklung und auffallendes Ungeschick in der Motivierung der Handlung" (4), "ungeschickt", "schwankend und unbestimmt" (5), "mangelhafte[n] Motivierung" (6) and attributes in the commentary, 16-45; see also the examples listed by Shewan 1911, 11-13. Though not defending their authenticity, Klingner 1940 elucidates the positive, artful aspects in the same phenomena. See, to some extent, also Reinhardt 1961, 243-250.

22 Examples listed by Ranke 1881, 7-11; Shewan 1911, 13-14.

23 Shewan 1911. Cirio 1998 follows in his footsteps; see the summary of the points criticized, her refutation 13-16, and arguments 16-53.

24 Dué/Ebbott 2010, 31-87.

25 Fenik 1964; according to him, therefore, the Doloneia is later; since it differs so much from these Cyclic versions, he concludes that a less gifted poet tried to fit it at all cost into the Iliad, 53, 61-63.

26 Fenik 1964, 5-8; Dué/Ebbott 2010, 89-106. 
dition obviously presupposes the mythic versions and subordinates them to the main plot. However, the fairytale motif of the magical horses and the survival of one dreadful night are transformed and combined with further elements so that the new tale almost erases the former vestiges. Moreover, it is central for my interpretation that horses and solar motifs are intertwined. ${ }^{27}$ By means of Dolon as a 'speaking name', the Rhesus myth is embedded into a story of disguise, deceit, spying, horse swapping and hunting. At last, only through a concatenation of facts and deferrals of information, Odysseus and Diomedes gain access to the miraculous power of the horses of Rhesus.

In sum, I argue that all strands of the tradition can be assimilated to the Homeric oral tradition. Gregory Nagy's evolutionary model can explain how in an agonistic context elements of other myths can be incorporated, as well as how single songs can be flattened, finished and transformed over generations so that they accurately fit into the greater frame of the story.

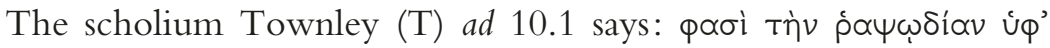

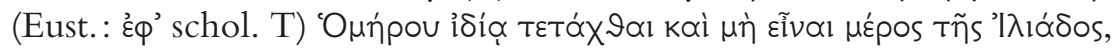

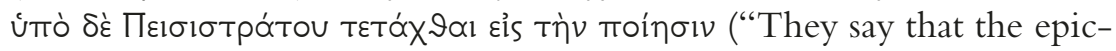
rhapsodic poem was composed separately by Homer [in Homer's time] and did not form part to the Iliad, but that it was arranged into the poem by Peisistratus"). ${ }^{28}$ Was then the Doloneia a single song, as the analysts wanted to make us believe? Even in the wild speculations of the scholium, the song was still Homeric, i. e. composed by Homer. ${ }^{29}$ The scho-

27 See the very brief remarks by Wathelet 1989, 226-230 on the solar theme and Dué/Ebbott 2010, 375 ad 10.547.

28 A slightly different version is reported by Eustathius 785.41-45:

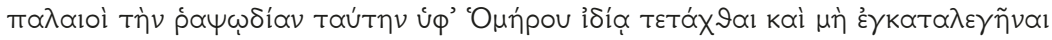

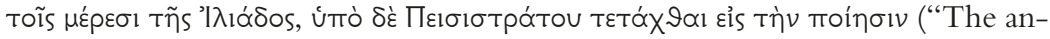
cients say that this epic-rhapsodic song was composed separately by Homer and not counted among the parts of the Iliad, but that it was arranged into the poem by Peisistratus").

29 Many ignore this fact; but Shewan 1911, 133-139, esp. 137; Cirio 1998, 18; Cirio 2003, 185; Dué/Ebbott 2010, 5-6. Normally the scholium is used as proof by the analysts: e.g. Ameis/Hentze 1888, 7-8; Leaf 1900, 423; Heusinger 1939, 9-12; West 2011, 233; see also, slightly different, Hainsworth 1993, 153 and Danek 1988, 236-237. For a useful analysis with a view on the scholium's peripatetic premises, see Cirio 1998, 16-22 and Cirio 2003, 184-187. Against West 2001, 10-11 who argues for a "Pergamene origin" of the scholium, Montanari 2010 interprets it as a reflection of the divergence 
liast seems to believe that the song of Dolon was a single song, a short rhapsody, and originally not part of the organic unit of the Iliad. Only at a later stage was it integrated by Peisistratus, obviously an allusion to the so-called Peisistratean redaction. ${ }^{30}$ Yet once upon a time, the Iliad itself was just a simple and much shorter song; slowly it was able to grow by embedding other mythic material and several simple stories. Under the Panhellenic and especially Athenian influence, in particular in the agonistic circumstances of the Panathenaea after the regulations of Hipparchus, the inconsistencies were reduced. It finally coalesced to the Iliad of the monumental size of twenty-four Books. The scholium elucidates as well that each song tradition is Homeric and that - at least in the time of Peisistratus - the Doloneia was part of the Iliad. ${ }^{31}$ Therefore, these results are entirely compatible with Gregory Nagy's model. The allegedly chaotic, burlesque, and almost comically grotesque features might find an explanation in contemporary 'theatricalizing' manners of epic performances, that is, in the interpenetration of theater and epic in Athens. Be that as it may, from this single source it cannot be concluded that one necessarily has to put the Doloneia in critical brackets. ${ }^{32}$ Rather, the entire issue depends on the stance on the Homeric question. For judging this song, the best approach is to project oneself into the oral situation of the audience's reception.

All in all, I believe that it is futile to speculate whether Book 10 is not genuine and a later addition. Without a shred of doubt, it is Homeric in matters of style and diction and therefore part of the Homeric tradition. In my opinion, a useful way to make progress in the understanding of the Doloneia in the context of the entire Iliad is the analysis given by Albert Lord in his Singer of Tales. In this groundbreaking book he shows the patterning inherent in Iliad 9 and 10 and discusses the possible

between the Chorizontes and Aristarchus, who, in a unitarian manner, regards the Doloneia as an organic and genuine part of the Iliad.

30 For the Peisistratean redaction, in an analytical vein, see Von der Mühll 1952, 7-10; for the evolutionary model, see Nagy 1996; Nagy 1996a; Nagy 2002; Nagy 2003; Nagy 2008/09; Nagy 2009/10; Whitman 1958, 353 n. 70 thinks the Doloneia is an older work of Homer's, and later restored. Shewan 1911, 4950 also questions the standard view that the Doloneia must be late. See also Cirio 1998, 15.

31 The early reception proves that the Doloneia was always thought to be part of the Iliad; see Dué/Ebbott 2010, 89-151. With regard to Aristotle, see also Cirio 1998, 18-19. For Aristarchus, see now Montanari 2010.

32 See the most recent edition by West 1998, 286, on account of the scholium. For a more detailed explanation, see West 2001, 10-11 and 2011, 233-246. 
duplications of both Books, viewing them as possible alternative links to Book 8 and "interchangeable" connections, at any rate "two versions of the story, which have been amalgamated". ${ }^{33}$

With the help of Lord's insights we can shed light on the patterns, narrative doublets, and substitutions in the Iliad. He makes us aware of how one motif grows out of the previous one and why the Iliad is told in the way it is. The smooth telescoping into the beginnings of the Trojan War provides the mennis-plot with its Panhellenic significance. Gradually the temporal order of the tenth year of battle is being dissolved, and the audience is taken back to the very start of the military events, the Catalogue of Ships. Before that, in Book 2, we see Agamemnon's peira, the false dream of Zeus, and the commander's defeatism of testing his troops through his order to return home. Zeus seems to immediately fulfill Thetis' wish to help the Trojans until they reach the Greek ships. The Argive king is completely mistaken in his strategic plan, since the masses of soldiers enthusiastically react to this call and take flight toward the ships. However, Odysseus is able to stop the wave of soldiers rushing backward and then builds up morale again. In the modulating backward-perspective of the following Books, the Greeks, instead of the Trojans, unexpectedly gain the upper hand over their enemies. This happens even without Achilles, their best fighter, who has retreated from the army in his dreadful wrath.

Lord has shown that Achilles' withdrawal and later return resembles the way a god disappears and comes back on the scene in form of an epiphany. ${ }^{34}$ Because the great hero Achilles refuses to fight, the Greeks are expected to lose control of the situation, but they steadily make progress. Diomedes takes over the role of Achilles and, until his wounding, becomes to some extent his substitute. The missing super-hero and his plan to gain satisfaction by punishing Agamemnon's hubris is brought to the audience's mind only at certain points. At the end of Book 7 and of the temporal telescoping process, we finally return to the mennis-timeline. The Greeks fortify their camp with walls and ditches to protect their ships, which the Trojans will nevertheless reach. Zeus grows angry and makes the battle ground resound with thunder. In Book 8, after having balanced his scales of death, on which the side of the Achaeans settled down to earth (Il. 8.69-74), Zeus meets the conditions

33 Lord 1960, 186-197, esp. 194.

34 For the treatment of time, see Lord 1960, 191; Latacz 1996, 128-132. For Achilles' withdrawal and return as an epiphany, see Lord 1960, 186-197. 
he had pledged to Thetis. For the first time after all the critical circumstances in Troy, Hector advances into the liminal space close to the Greek ships and, at the end of the quarrel with Hera, Zeus provides the listener with a clear orientation of how the action will develop in the future (Il. 8.470-477).

Before Hector can reach his strategic goals, night falls suddenly. At the last moment, the Greeks are saved, perhaps only for one more day. The situation is extremely precarious. I argue that Books 9 and 10 which, together with many passages of Book 8 , were severely called into question by various analysts, ${ }^{35}$ intensify the effect of the deep crisis and present background to the audience. Iliad 9 focuses on Achilles, who has been off the scene since his withdrawal in Book 1. In desperation, Agamemnon is about to concede defeat and to dismiss his plans; in a speech he calls on the army to sail home - the situation now resumes and reflects the situation of Iliad 2, the peira. Diomedes, the second best and substitute of Achilles, intervenes and retorts that he should go alone; they, the Greeks, would continue fighting. Nestor calls an assembly, criticizes the commander in chief, and Agamemnon admits his terrible mistake. He is therefore now ready to pay rich compensation. Since the only hope of rescue lies in Achilles, they send out envoys to beg him (Litai) to return to battle. Yet the mission fails, and we are thus thrown back to the grave situation at the beginning of Book 9 .

Bryan Hainsworth maintains that Book 9 has no actual end in the plot of the Iliad ${ }^{36}$ - and there have been debates about the authenticity of this section as well. ${ }^{37}$ Yet, Book 9 aims at bringing Achilles back into focus and shedding new light on his character and motivations. Despite all attempts, he refuses to yield. Thus, the mission has failed; at this point, it is again Diomedes who speaks up in the assembly and lifts the morale again by urging the army to fight without Achilles: since the commander of the Myrmidons had threatened to go home, he should do so; the Greeks should just leave him alone (maybe he will come back when the gods incite him to do so sooner or later). At this point in the evening they should eat and rest, and tomorrow they

35 For Book 8 and its unusual proportion of plus-verses, see Kirk 1990, 293-294; Ameis/Hentze 1887, 64-85; for Book 9, see Ameis/Hentze 1887, 108-135. See also the balanced treatment from a neo-unitarian perspective by Reinhardt 1961, 138-242.

36 Hainsworth 1993, 56: "But to the action of the poem the Book contributes nothing, ..."

37 See Ameis/Hentze 1887, 108-135. 
should resume the battle (Il. 9.697-709). As Klingner rightly observed, Book 9 extends the day into a long evening, whereas Book 10 is just about the night, which is stretched out into the next morning. ${ }^{38}$

The Doloneia is certainly not in conflict with the overall situation. Even though another Book is not indispensable to the basic plot like Iliad 9, it does not lead to anything and stands to some extent apart from the rest of the epic, as has been repeatedly observed. Obviously, in an evolutionary process the expansion has been well integrated into the body of tradition. The variation of Book 10 does not focus on character, but on atmosphere and symbolic signs. It deepens the hiatus, makes the night the major theme, and highlights it. Furthermore, it helps to break the impasse and to advance the process of transition. Since the entire design and all the particulars of Iliad 10 are completely different and beyond the expectation of high epic poetry - the heroes behave unheroically, the mode of narration plays with strange concatenations and twists, every detail is mirrored, the protagonists disguise themselves in strange costumes and commit brutal and dreadful deeds, the atmosphere is eerie and terrible, and the focus is placed on the biotic and on lowbrow facts - critics have argued for a poem composed later and inserted into the Iliad. Yet the expansion of the narrative does have a function: it lies, as I suggest, on a different level, on the symbolism and on the atmosphere. Furthermore, the Book serves to deepen the crisis and to explain how the Greeks regained their confidence and strength. ${ }^{39}$

\section{The Plot of Iliad 10}

Book 10 is perfectly joined to the situation of the end of Iliad 9, besides the fact that the leaders do not refer back to the disappointing result of the presbeia, as if they do not know about it. But it is tacitly taken for granted, and this is the reason why the commander is so desperate in spite of Diomedes' appeal, which has raised the army's spirit for a short while. The night continues, and everybody has gone to bed. However, Agamemnon cannot sleep again (a variation on Book 2), and is full of fear. He decides to go to Nestor, "he who brings back

38 Klingner 1940, 359-361.

39 For the latter point, see already e.g. Bäumlein 1856, 425-426; Shewan 1911, 143. 
to life and light", ${ }^{40}$ for counsel. On his way, Agamemnon meets his brother Menelaus, who is trembling as well. The thematic focus changes for the first time because Menelaus asks why Agamemnon has dressed up and whether it is because he is sending out someone for spying (Il. 10.37), a very daring job that requires a lot of courage. The situation then oscillates permanently between the plan to call a meeting - a variation on Iliad 2 and 9 - for counsel, the desire to check the guards, and the idea to go out there to spy and perform a brave deed. ${ }^{41}$ The assembly is not an official one, but includes only the leading figures and it should take place outside the camp on the frontline, where the guards are stationed. This is the strategic scenario into which everything has to fit. Due to the onset of night at the end of Book 8, fighting has come to a halt. In such a dangerous and critical situation, Agamemnon and Menelaus are in need of good advice, despite the fact that they had just received it from Nestor in Iliad 9. Moreover, they want assurance that the guards are on their posts, and they are eager to obtain new information about the intentions of the enemy. Spying is the only possible way to get more strategic knowledge. Each extension has to be accommodated to this realistic military picture. The ongoing shift of focus has been criticized as inconsequential and unmotivated. ${ }^{42}$ Yet I would argue that it mirrors well the nervous fickleness of mind, the desperate desire to do something where not much can be done.

From his first plan to rouse Nestor from sleep in order to receive counsel, Agamemnon thus changes his intention to call a new assembly. Therefore, he starts with a frantic wake-up initiative. He gives orders to his brother to go and get Ajax and Idomeneus; yet not even Menelaus understands the exact sense of where to meet at this point. Agamemnon clarifies: he should wait there, because there are many paths (Il. 10.66) this could be a metapoetic reference to the many paths of interweaving and variation in the process of textualization. Agamemnon himself goes to Nestor. As a special informant, the old and wise king of Pylos recalls Achilles and predicts more troubles for Hector in the future (Il. 10.103107). Then, they awaken other teams of comrades, starting with Odys-

40 Frame 1978, 96-115 and Frame 2009, 23-102.

41 For the analysts, this is a proof of a lack of focus; e.g. Ranke 1881, 50-54; Klingner 1940, 339-351 interprets it as a sign of artful intention; see also Reinhardt 1961, 243-244.

42 Ameis/Hentze 1888, 4-6; see also Heusinger 1939, 38; Ranke 1881, 21 -26 in relation to the surrounding books, and 50-54. 
seus and Diomedes. Furthermore, Nestor criticizes Menelaus for having been inactive (Il. 10.114-118). Yet Agamemnon defends his brother in tender tones: ${ }^{43}$ he has woken up before and is already out to search for Ajax and Idomeneus (Il. 10.120-125). When Diomedes displays his unwillingness, Nestor reminds him of the fact that the situation teeters on a knife's edge (Il. 10.173). In a kind of relay, one man has to rouse the other. This almost comic and detailed description of waking up the heroes is somehow similar to the famous entrance scene in Aristophanes' Ecclesiazusae $(1-278) .{ }^{44}$ Moreover, the length of the scene, criticized as disproportionate, could again be a metanarrative reference to the relay-like performance of the various songs that have grown together over a long period of time.

The leaders leave their fortified camp to go out to the guards, and then over the ditch in a no man's land of death and bodies (Il. 10.194-202) to hold the assembly. Nestor immediately gives the advice to send out a spy to collect more information about the intentions of the enemy (204-210). Diomedes, Achilles' substitute, has the courage to undertake the enterprise, and he will earn the promised kleos (212-217). Yet he suggests that a second man should accompany him $(220-226)$. In a variation on the selection process in Book 7, Agamemnon wants to spare Menelaus (240). Diomedes should take whom he wants to choose and not be influenced by rank or prestige (234239). Thus, he selects Odysseus, the specialist in night excursions, of $10-$ khos, dolos and mêtis, and the protegé of Athena (242-247). Odysseus declares his readiness and asks for action, since two thirds of the extensive night are already over (249-253), also due to the time-consuming embassy in Book 9. In a special arming scene Diomedes, already dressed in the hide of a lion (177-178), puts on a kuvén of cow leather (257259), and Odysseus the famous boar's tusk helmet (261-265), inherited from his grandfather Autolycus, the werewolf par excellence. Both have left most of their armament in the camp and receive it now from Thrasymedes and Meriones, who accompanied them to the guards. Thus, the way out of the camp to the posts of the watch receives a belated and additional justification. ${ }^{45}$ The masquerade and all ritual associations mark the scene as a diachronic regress into very older, atavistic strata

43 Reinhardt 1961, 244.

44 For the comic tones, see Shewan 1911, 199-204 who wants to play down these pejorative attacks on the Doloneia on the basis of his aesthetic preferences.

45 See Reinhardt 1961, 246-248. 
and as a symbolic path to darkness, death, and the 'Other' ${ }^{46}$ Both depart and pray for the support of Athena, who is notoriously on their side (272-294). Diomedes mentions his father Tydeus who, on his way back from the Theban expedition, committed a grim and brutal carnage. As his son, he begs for the same support on a similar massacre and dedicates in return the moderate victim of a heifer whose horns he promises to drench in gold (284-294). Like two lions, both heroes now sneak over bodies and death (Il. 10.297-298).

The entire Doloneia is characterized by antithetical mirror-scenes and analogical reversals. Thus, the Trojans both have the same concern about their Greek enemies and initiate a spying operation. In a mood of exaggerated optimism and hubris, Hector entices the soldier who will spy for the Trojan side by promising him Achilles' horses and carriage. The fast but ugly and simple-minded Dolon, bearing his 'speaking name' from dolos, 'deceit', volunteers. However, he does not trust his ruler. Therefore, Hector has to swear holy oaths, horkoi (299-331), as before the duel between Paris and Menelaus in Book 3. Then, Dolon gets dressed in a guise that is even stranger than that of the two Greeks - Agamemnon (like Diomedes) has already been described as wearing the hide of a lion, and his brother that of a leopard (Il. 10.23 and 10.29); Dolon puts on a wolfskin and a helmet of ferret's fur (Il. 10.334-335), and leaves for his mission as well. As Diomedes and Odysseus hear Dolon approaching, they hide among the dead bodies (349-350), jump out from their ambush and hunt him down (Il. 10.339-374). Fearing for his life, he trembles (374-376) and even promises - while assuming the posture of a suppliant - a large sum of money as ransom (378-380), a clear reminder of the Chryses scene in Iliad 1. In desperation, Dolon tells them everything: he reports

46 For the boar's tusk helmet as reference to bronze-age equipment from the 16th to the 15th centuries BC, see Hainsworth 1993, 179-180 ad 261-265; see also Stubbings 1962, 513-517, esp. 516 on Mycenaean graves. According to Hainsworth 1993, 180, the gear characterizes the spirits of the persons who wear it; similarly, in symbolic terms, Schnapp-Gourbeillon 1981, 119-121 = 1982 6466. Against arguments of an allegedly archaizing manner, see Shewan 1911, 189-198, esp. 197-198. Also in a naturalistic manner, van Leeuwen 1912, 341, and now also Dué/Ebbott 2010, 291 ("completely appropriate for a night raid") and 295. For associations of the kuvé $\eta$ with death and Hades, see Il. 5.845, where Athena gives the "helmet of Hades" ("Aıઠos kuvénv) to Diomedes to make him invisible in his duel with Ares. See also Jeanmaire 1939, 400 . 
how he was lured into his mission by Hector's promise to win the horses of Achilles (391-393). Odysseus replies mockingly that only Achilles can command them anyway (401-404). Then, Odysseus interrogates Dolon as to where Hector and the Trojans are disposed and where they have their horses (405-408). Dolon blabs the whole story in detail and, without being asked, reveals secrets regarding the allies and Rhesus (413-441). He reports that the Thracians arrived last of all and tells where they are positioned, among them their leader Rhesus with his beautiful, white horses, his brilliant weapons and his carriage, a miracle for all to wonder at and a sign of the immortals (434-441).

With this information, the Greek heroes who had gone out for reconnaissance and for the sake of glory find a greater goal. The whole story is about metis - to trick the trickster Dolon and to make him betray new objects for their raid. ${ }^{47}$ Despite Dolon's supplication, the violent hero Diomedes brutally decapitates him. Then, Diomedes and Odysseus strip Dolon's bloody armor, his fur and helmet, and put it up on a tamarisk tree as gift for Athena in recompense for her showing them the way to Rhesus and his horses, and a sign or marker to find their way back (454-468). Next, they advance over blood, bodies and war gear to find the Thracians $(469-470)$. It is, again, Diomedes who takes over the business of killing the twelve Thracian warriors and, as the thirteenth man, their miraculous leader Rhesus. Odysseus, on the other hand, drags the bodies out of the way and releases the magical horses from the yoke (471-502).

As soon as Athena admonishes them to hurry, they ride on horseback. On their way back, when they pass the tamarisk, Diomedes jumps down to collect Dolon's bloody arms, and they flee toward the Greek camp (513-531). Nestor is the first to hear the noise of hooves (532). When he finally sees his friends returning from their dangerous mission, he asks them how they got these miraculous horses, "more bril-

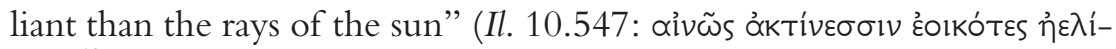
o10). ${ }^{48}$ Finally, they are led into Diomedes' stables, while the Greek sol-

47 For a poetics of mêtis, see Schnapp-Gourbeillon 1981, 107-108 and SchnappGourbeillon 1982, 53-54; Petegorsky 1982, 175-254 applies a thematic approach and argues $(177-178)$ that the Doloneia is spun from Achilles' challenging remark that the Greeks will have to find "a better metis" (Il. 9.423) to save the ships and men (9.421-426); see Dué/Ebbott 2010, 102-103.

48 The Homeric Greek text is cited after West 1998, the translations are, with slight modifications, from Lattimore 1951, except at very few places, as here, where I give my own for reasons of being even closer to the Greek. 
diers rejoice in jubilation. Thereupon Odysseus lays down Dolon's bloody spoils in his ship for Athena. Both heroes then go into the sea, bathe, and eat breakfast (564-579). Immediately afterwards in Book 11, the formerly demoralized and disoriented Agamemnon undergoes his aristeia, and as a result, the Greeks enjoy some military success.

\section{The Function of the Doloneia}

Instead of simply referring back to the beginning of the poem like Book 9 , this story does have a purpose. Contrary to the assertion that it leads to nothing - on account of which many critics have concluded that it was a later addition - it advances the plot, though on a deeper and symbolic level. The morale of the Greeks is still rather low, even after Diomedes' encouragement at the end of Iliad 9 where the focus was primarily on Achilles and on the ethical background. Book 10 functions on a very different scale. I argue that the Doloneia symbolically highlights and underscores the transition from crisis, night and death to new life, sun, daylight and energy. Book 8 represents the first short day of combat in the menis-plot (the second day of combat in the Iliad) and ends with the near defeat of the Greeks; however, the sudden arrival of the night

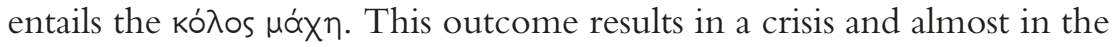
total collapse of both Agamemnon and his army. Along with these developments, the Greeks are in great danger and are therefore terribly frightened. A good epic poem aims at raising the emotions of the audience, because people wish to have compassion for their heroes. Thus, an óoıós hopes to create mó $९$ os, suspense, and emotional impact through

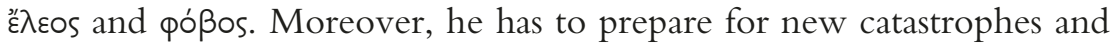
developments through proleptic information or symbolic underpinnings.

The plot of the Iliad focuses on figures and their actions in the time frame of the Trojan War and evolves in an abstract scenic landscape situated between the Greek ships, the newly erected walls around them and the Trojan fortifications. As in a board game, the movements of the figures go forward and backward: if one side loses an important player, the opposite party gains strength and moves forward, or vice versa. $^{49}$

49 See also Clay 2007. 
As emphasized above, the crisis of the Achaeans is exacerbated by an endless night of fear and foreboding that extends over two Books ( 9 and 10). How can the Greeks gain new momentum and fresh energy to effect a turn of the events and to escape from such a desperate situation? We recall that the embassy to win over Achilles had failed. After Iliad 9, the Greeks are a bit more optimistic because of Diomedes' leadership. However, one speech cannot be enough. Only during the eerie night can the crisis really be felt. Yet with Book 10, the reversal of the situation gains momentum and becomes part of the narrative design. Books 9 and 10 function as a hinge between the second short day of battle (Book 8), after the reprojection into the beginning of the war in Books 2 to 7 (first day of combat), and the following extensive one (third day of combat, Books 11-18) where the decisive peripeteia in the menis-plot with Achilles' return after the death of his surrogate $\mathrm{Pa}$ troclus will take place.

The singer uses a number of different patterns to engage the audience in his performance: the frightful atmosphere is conveyed through the night, as well as through the gloomy operation of deceit and lokhos in the realm of the 'Other' and death. Furthermore, the poem diachronically shifts into modes of a primordial past, which means the narration of the episode proceeds almost in the manner of a humnos, in the former epic method of storytelling. ${ }^{50}$ Thus, the movements are fast, one action evolves from the previous one, and both enemies execute one step that is reciprocated by the other on the opposing side. ${ }^{51}$ The trickery consists in an agonistic and traditional form where the move of one party operates on the basis of the same trick of the other party and reverses it. The symbolic regression into an atavistic past is highlighted through some marked forms of military equipment, such as strange helmets and animal furs. This shift in time is paralleled by a shift in tone, style, narration and atmosphere. In structuralist terms, we can observe a change from men to animals, from the cooked to the raw, from civilization to savagery.

50 On Demodocus' Song of Ares and Aphrodite in Homer's Odyssey 8.266-366 as humnos in a diachronic shift, see Bierl 2011.

51 See Bierl 2011. In both passages the fast change of action is marked by the for-

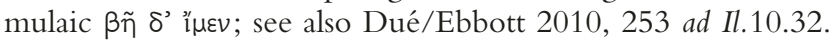




\section{Mythic and Ritual Patterns}

Moreover, the gloomy aspects in the Doloneia are emphasized by further primordial patterns of ritual and violence. The ritual-mythic design helps to convey fear and to intensify the transition. ${ }^{52}$ The Greeks have to go through a worst-case scenario and teeter on the brink of disaster. Therefore, above all the narrative of overcoming the deep crisis is assimilated to the general pattern of a rite de passage. The ritual-mythic elements serve as a kind of generator of signs and node of energy to communicate meaning. Several scholars have shown how, to some extent, both Dolon and the Greek pair reflect patterns of initiation, the werewolf, human sacrifice, the pharmakos ritual and the New Year. ${ }^{53}$ One might even add the scheme of the shamanistic quest for knowledge through the excursion into the realm of the 'Other' and death. ${ }^{54}$ Death experience, "black hunters", trickery, dolos and mêtis, animal disguises, journeys into marginal and liminal spaces as well as into the territory of the 'Other', fights with monsters and demons, and swapping are typical of a rite of passage which serves as the overall ritual-mythic structure in this case $:^{55}$ in short, one encounters death in order to overcome terrible danger.

In the typical manner of a mythic-ritual poetics, all paradigms are intertwined, ${ }^{56}$ and the signs function to emphasize the transition. They do not reflect a real situation or a specific rite but are a narrative

52 For a ritual-mythic poetics, see Bierl 2002; Bierl 2007 and Bierl/Lämmle/Wesselmann 2007; for a ritual poetics, see Yatromanolakis/Roilos 2003.

53 For a reading in terms of initiation and werewolves, see Gernet 1936; Jeanmaire 1939, 387-411, esp. 399-401; Davidson 1979. Schnapp-Gourbeillon 1981, 104-131 questions this ritual approach and aligns animal skins with symbolic signs; furthermore, she brings the pharmakos and human sacrifice into the discussion; see also the extract in Schnapp-Gourbeillon 1982; for an analysis in terms of initiation, werewolves, and human sacrifice, with emphasis on the "ritualism" of the pseudo-Euripidean Rhesus, see Bernacchia 1990, esp. 4653; for a more nuanced ritual reading, see Wathelet 1989; in terms of folktale, see Davies 2005.

54 See Bierl 2009.

55 See Bierl 2007, 23-25 and the list of signs in Bierl 2007a, 265-276; for the "black hunter", see Vidal-Naquet 1968; for mētis, see Detienne/Vernant 1978; for images of Dolon, see Lissarrague 1980.

56 Bierl 2007, esp. 51-52; Bierl 2007a, esp. 319-320. 
tool of causing the listener to become involved in the story. ${ }^{57}$ This can be done by means of variation, combination, distortion, reversal and inversion of a pattern. To avoid a frequent misunderstanding, I do not claim that these allusions represent a means to accessing the possible origins through which literature could be explained as an evolution from real-life experiences, but rather a narrative strategy to communicate symbolic meaning. Merely from the resulting ambiguity, one can conclude that it is impossible to pin down this episode to one single rite or myth. Rather, the overdetermination of signs has the narrative purpose of conveying the atmosphere of uncanniness, fear, and crisis. In particular, the pattern of Lycaon and werewolves or secret societies of Männerbünde dressed as tiger men or leopard men $^{58}$ helps to make the oppositions of life and death, day and night, light and darkness collapse. ${ }^{59}$ The cannibalistic deinon - in Il. 10, of course, they still refrain from eating the flesh, but in his rage Achilles even alludes to the practice in Il. 22.346347 - often has cosmic implications, namely, the eclipse or reversal of the sun. All mythic and ritual traditions of this pattern re-elaborate $\mathrm{Pa}-$ leolithic practices in which, by donning the skins of predatory animals, hunters helped mankind to live on.

Often narratives fantastically combine all sorts of ritual signs. As Euanthes reports, the initiate as werewolf takes off his clothing and puts it up on an oak tree in order to swim over a lake or to cross the border to a marginal place where he stays for nine years. ${ }^{60}$ If he has not eaten from human flesh he will return. ${ }^{61}$ As in all patterns, certain mythic-ritual elements concerning the Lycaea and Lycaon are refracted, fragmented and recombined for the storyline in $I l$. 10: Dolon disguises himself as a wolf and takes on the role of Lycaon. Odysseus himself is descended from

57 Schnapp-Gourbeillon 1981, 113-114 = 1982, 59 criticizes Gernet 1936 and others for neglecting the textual context and warns that "la chasse systématique au rituel a tendence à appauvrir le text, à le réduire au rôle de miroir - deformant - d'une réalité sociale" $(119=64)$.

58 Burkert 1983, 88-89.

59 For the myth and ritual, see Piccaluga 1968, esp. 15-98 and Burkert 1983, 8493. For the pattern, ibid. 83-134. For Burkert as inspiration for literary interpretation, see Bierl 2010a, esp. for Homer 10-11, 19. For the background of the Doloneia, see Gernet 1936; Davidson 1979.

60 Euanthes, most likely Neanthes of Kyzikos, FGrHist 84 F 41 Jacoby = Plin. N.H. 8.81 .

61 See the story about the boxer Damarchus who "turned into a wolf at the sacrifice for Zeus Lycaeus and turned back into a man in the tenth year", Paus. 6.8.2. See also Paus. 8.2.6. 
Autolycus, the wolf and trickster par excellence, ${ }^{62}$ and Diomedes, like his father Tydeus, performs dreadful deeds that recall a human sacrifice, just as his Thracian counterpart possesses cannibalistic horses. ${ }^{63}$ In the Rhesus (lines 219-220), the pseudo-Euripidean tragedy of the 4th century BC, Dolon goes out to obtain Odysseus' head as a trophy, while in Iliad 10 he is decapitated himself. Dolon does not lay down his clothes, but he will be deprived of his armor after his death. The gear is deposited on a tree, the tamarisk (Il. 10.458-468). This act recalls, to some respect, $\mathrm{Pa}-$ leolithic hunting rituals and funeral practices of collecting and depositing the bones of the dead animal in trees or on poles. ${ }^{64}$ In a way, as a Trojan combatant, Dolon has been in the marginal situation already for nine years, but for the newcomer Rhesus, it is the very beginning of the war. Dolon might be described as пооб́кns, and the chase after him is assimilated to a footrace because in ritual, the sacrifice is often followed by athletic games, particularly by a competition in racing. ${ }^{65}$ As noted, in ritual, after their successful return from the realm of the 'Other', the initiates are ready for the agōn. The tragedian Lycophron (481) calls the murdered boy Nuktimos, 'the night-like', and makes him Lycaon's own child. ${ }^{66}$ The terrible deed occurs in a 'precinct that nobody is allowed to enter', an $\alpha \beta \alpha$ tov, comparable to our marginal territory of

62 Burkert 1983, 120, in the Delphic context of the pattern, 116-130.

63 Alden 2000, 143-149 regards the Doloneia as a "poet's manipulation of a story shape in his repertoire to provide a characteristic parallel with the account of the infiltration of enemy territory by Tydeus and his slaughter of Thebans in their own territory in books 4 and 5" (149); or in other words, she argues that Iliad 10 has its function and purpose merely in a variation and expansion of the raid theme in Il. 4.370-400, alluded to in Il. 10.284-294. On the merging of both Diomedes figures, see Bethe 1903, 817 and Davies 2005, 34.

64 Meuli 1946, 232-236 (= Ges. Schr. II, 957-963) describes funerals of bones and skulls of hunted animals on stakes or trees; esp. $234(=958)$ n. 5; instead of the bones, in the Doloneia the armor, the animal fur, the helmet, and the spear, is put on a tamarisk bush, and the twigs serve as sema, which in Greek means 'signpost' and 'tomb', Il. 10.458-468. See also Burkert 1983, 12-14, 66. He shows (66) that the tropaion, a stake adorned with helmet, shield and spear, to which the skin of the goat sacrificed before the battle is added, represents Athena with her aigis. In the Doloneia, Dolon's armor is dedicated to Athena. For the symbolic meaning of the tamarisk, esp. in the context of prophecy, see Wathelet 1989, 221 n. 35.

65 For the Lycaea and Olympia, see Burkert 1983, 92, 97-98.

66 For Pelops at Olympia as the 'dark-face', see Burkert 1983, 97. 
the battlefield into which Dolon trespassed. Therefore, he must be sacrificed. ${ }^{67}$

At Delphi, we similarly find such gloomy myths and rituals. Young men who are about to sacrifice or robbers themselves are brutally killed in the sacred precinct by locals with knives. Two groups confront each other, that is, worshippers who in the guise of wolves search for the god in the wilderness and encounter his greedy servants who steal the sacrifice. The god is Apollo Lyceios, associated with 'light' and 'wolf. The opponent of the wolf's son is a 'ram'. ${ }^{68}$ It becomes obvious once more how various ritual-mythic elements resonate with the Doloneia in variation, combination and reversal. The ritual victim is often a kplós, a ram, or a female lamb or a black goat. ${ }^{69}$ Such a black sheep is promised to Diomedes and Odysseus in reward for their brave deed (Il. 10.215216)..$^{70}$

At Delphi, the Septerion, ${ }^{71}$ a festival of "fear", "theft", and "flight", was celebrated every nine years. A special cathartic rite carried out during the night was called the Dolonia, which obviously can be associated with the Doloneia. In it, members of the Labyadae lead in a young and pure boy to destroy the central wooden building, a hut imitating the king's palace. After destroying the order through violent attack and cunning (Dolonia), they all flee without turning, just as Odysseus and Diomedes do in the Doloneia. ${ }^{72}$ The rhythm of the ninth year refers to the

67 See Burkert 1983, 91 with sources. For the ritual spectacle of the Delphic tripod in a sacred precint, åsutov, see Burkert 1983, 116-130.

68 See Burkert 1983, 118-121.

69 For the black ram as victim for Pelops as a sign of marginality, see Burkert 1983, 98; for the black sacrificial animal, ibid. 153; for sheep, rams, lambs, and goats, ibid. 106-108, 113-115, 118-119, 121-122, 125-126. The shudder of the goat-victim as sign of "quaking fear" (125-126) could perhaps be associated with the quivering fear of Dolon in Il. 10.374-376, often seen as a typical exaggeration and proof of inauthenticity, e. g. Stoevesandt 2004, 157-158.

70 For the difficulty critics had with this passage, see Shewan 1911, 185-186 again with a naturalistic explanation.

71 Plu. de def. or. 417e-418d; see Burkert 1983, 127-130.

72 Plu. de def. or. 418a; Burkert 1983, 128-129 relates it to the Doloneia; see also Gernet 1936, 197-198 and Jeanmaire 1939, 395-401, esp. 399-400. In a wild speculation, Usener 1904, 313-339 (= Kl. Schr. IV, 447-467) associates the destruction of the wooden building with the fall of Ilium, originally the cave of the dragon. The festival, earlier called Ilea, taking place in the month Ilaios, would have a mythological equivalent in a story of the destruction of the castle where a daimon or dragon keeps his prey. Apollo defeats him, acted out by Dolon and the young boy. The Il. thus would be a later reflection of a ritual. 
intercalary year of the old calendar system, thus marking a special critical period of transition. With this narrative pattern of the werewolf, Burkert also links Odysseus, whose grandfather Autolycus showed him how to hunt at Delphi on Mount Parnassus. ${ }^{73}$ As Burkert remarks, in the ritual-mythic structure the "antitheses" of night and day, darkness and light, death and life, hunter and hunted, sacrificial killer and victim "do not merely collapse into a uniform duality", but they "are, rather, generally transformed, each into the other." "74 This strange configuration of signs thus functions as a generator of new symbolic signs that constitute the Doloneia and underpin the transition from night to day, from darkness to light, from death to life.

\section{The Doloneia as a Katabasis}

As I have argued above, a passage is often symbolically expressed through the experience of death and the 'Other'. Therefore, Iliad 10 is designed on the pattern of a katabasis, a journey to the underworld and the return to life. Although it is almost unanimously stated that the Doloneia is completely self-contained without any links to other Books, it is, in this respect, well connected to Book $24 .{ }^{75}$ On such journeys, a hero descends to Hades in order to bring something or someone up to earth. For example, Heracles goes down to fetch Cerberus and rescues Theseus, who along with Peirithous had attempted to abduct Persephone. Orpheus descends to bring Eurydice back to earth, Heracles Alcestis. Dionysus visits the netherworld to fetch Semele, and in Aristophanes' Frogs, even the tragic poet Euripides is brought back to Athens. In the Doloneia, Diomedes and Odysseus, who experiences a kata-

73 Burkert 1983, 130-134; he references the circular, pointed hat of felt, the pilos, otherwise worn by Hephaestus and the Cabiroi, and associates Odysseus with their mysteries. In Il. 10.265, it is noted that the pilos was in the center of his famous helmet.

74 Burkert 1983, 93.

75 For associations of Iliad 24 with a katabasis, see Herrero de Jáuregui 2011 to whom I owe the idea of linking Homer with the Orphic gold leaves; see already Whitman 1958, 217-218; Wathelet 1988. For connections with the underworld in Iliad 21, see Mackie 1999. Wathelet 1989, 229-230 suggests briefly a descent in the "Autre Monde" in Iliad 10; however, I do not share his opinion that Dolon has to do with Hermes. For the Doloneia as a reflection of a katabasis, see also Davies 2005, 33. 
basis in the Odyssey, ${ }^{76}$ enter a territory that is closely related to death in order to carry off Rhesus' horses.

Moreover, other elements resemble hexameter poetry about the afterlife as well, where souls arrive at the gates of Hades. Thus, the Doloneia resonates with some passages from the Orphic-Bacchic gold leaves. Although they date later, we can assume an oral continuity of epic formulas and traditional concepts that go back to the formative phase of epic. Thus, some ritual ideas about the experience of the souls in the underworld could be incorporated into the Homeric tradition. At the same time, they can be recognized as belonging to this set of notions and motifs through specific and marked expressions. Variation, combination, distortion, reversal and inversion of the narrative pattern are decisive in this case, too. The intense trepidation of Agamemnon (Il. 10.9-10), his трómos, resembles the fear of the soul. ${ }^{77}$ Menelaus

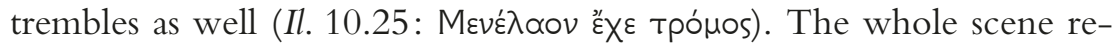
calls the first category of the Orphic-Bacchic gold leaves in which the soul of the initiate seeks instructions on how to get to Hades and how to encounter the guardians. ${ }^{78}$ Moreover, the tpómos foreshadows the threats of the symbolic road to Hades, the battlefield at night. In order to receive new information, one has to send out an ह̇тібкотоо (Il. 10.38), who should "sneak alone through the ambrosian night and

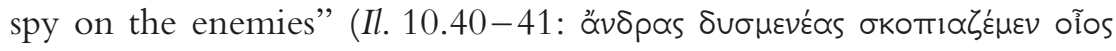

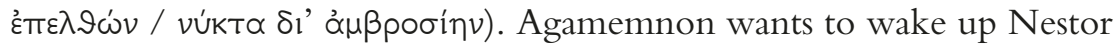
and encourage him to go to the holy group of the guards and to give orders (Il. 10.56). The guards are, of course, positioned on both sides of the combat zone. In strategic terms, Agamemnon is merely afraid that they might have fallen asleep (Il. 10.97-99). The landscape has all the features of marginality: it is full of dangers, and one can easily lose one's way (Il. 10.66). When Nestor wakes up, he asks Agamemnon about his identity and intentions (Il. 10.82-85). After revealing his name, the king of Mycenae expresses again his immense fear (Il. 10.93-95). The wake-up relay conveys the atmosphere of overcoming sleep and paralyzing fear. Finally, they reach the guards - in

76 For the conflation of a necromancy with a visit to the underworld in the Nekuia (Od. 11), see Clark 1979, 37-78; for the entire adventure stories (Od. 9-12) as death experience, see Hölscher 1988, 103-169; also Bierl 2008, esp. 173-176 and Bierl 2010.

77 For tpómos ('trembling fear'), see Il. 24.170.

78 See e.g. the Hipponion tablet OF 474 Bernabé. 
this case, and contrary to the souls in the Orphic leaves, not to question them about the ways in the underworld, but to see them active in their duty. Yet it was complicated enough not to become disoriented. Then, they clearly pass the border into another area of the no man's land of Hades. Thus, they cross the ditch and enter a place full of bodies (Il. 10.194-202) ${ }^{79}$ where they hold their strange assembly.

The rest of the Doloneia is sketched on a mission to advance into even deeper realms of the underworld. Diomedes and Odysseus step over "murder, bodies, weapons and black blood" (Il. 10.298: پ̊̆ $\mu$

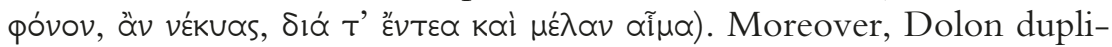
cates the same model in a reciprocal way. When Diomedes and Odysseus catch him, Dolon trembles again full of fear - he "stood still in terror gibbering, as through his mouth came the sound of his teeth's chat-

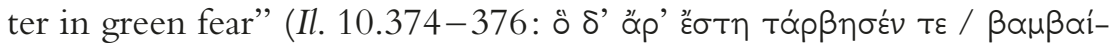

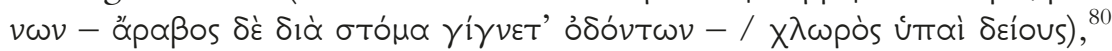
like the soul of the initiate reaching Hades. At this point, Diomedes and Odysseus, who, according to the pattern, had played the part of the arriving souls, take over the role of the new guardians and informants of Hades. Dolon adopts the role of the typical supplicant even though in his terrible situation as captive he is about to initiate his gesture only in lines 454-455. In a clear allusion to the marked ঐápoєl (10.383: 'have courage!'), ${ }^{81}$ Dolon receives encouragement and apparent salvation. Yet in fear, the simpleton Dolon tells all that he knows, whereas in the state of affairs described in the golden leaves, he should receive news. Thus, the ritual situation is again reversed to a trick in order to gain information from the enemy. Polumetis Odysseus interrogates him about the circumstances, then about Hector and his horses (Il. 10.406-407), and the location of the guards, and Dolon reveals the fact that the allies are asleep (Il. 10.405-422). With these catchwords, Odysseus conceives of the idea to start his raid and asks about the whereabouts of the allies. Dolon mentions, among others, the newly arrived Thracians, who are separate and beyond all the others,

79 See esp. 198-200: "After they had crossed the deep-dug ditch they settled on clean ground, where there showed a space not cumbered with corpses of the

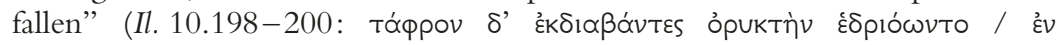

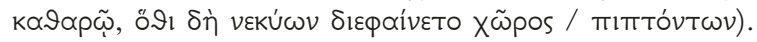

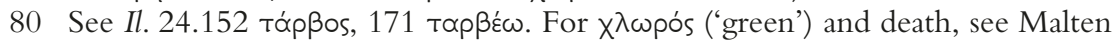
1914, 188.

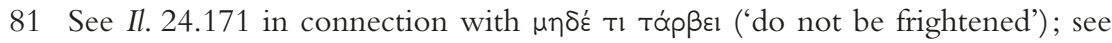
also Il. 24.181. For Эápఠє1, see also 4.184. 
with their leader Rhesos and his supernatural horses (Il. 10.426-441). Finally, the Greeks have a new target on their night raid that promises even more glory. Dolon's supplication must fail then: the imperative ᄀópoєı (Il. 10.383) was never meant seriously, but Diomedes and Odysseus act like terrible demons of death after decapitating the 'initiate' who is just about to make the supplication (Il. 10.454-457). ${ }^{82}$ The markedly ritual encouragement thus exhibits an uncannily ironic tone.

\section{Folktale Motifs and Wondrous Tales}

These narrative patterns are overlaid with motifs of folk-belief and fairytales $^{83}$ as well as with specific narrative modes in which function is more important than character. Odysseus is the typical helper-figure, and, moreover, the seeker in the realm of darkness and death. In the terminology of Vladimir Propp, we have the typical situation of lack, and this lack will be liquidated. ${ }^{84}$ The story departs from a realistic situation concerning a military crisis. There is allegedly a lack of information and counsel. Therefore, a sort of assembly is summoned, and Nestor gives the advice to spy on the enemy. This situation is mirrored within the other party, and it typically operates on the same basis as the previous move: the Greek spies run across a spy of the Trojans. They literally pump Dolon for information about strategic issues concerning the enemy. However, this rather realistic scenario is transferred to another, more symbolic level of quest, that is, to the shamanic pattern where extraordinary people go on a mental journey to the beyond to seek some paranormal power. ${ }^{85}$ Without being asked, Dolon, the 'trickster' who is eager to win Achilles' horses for recompense, mentions the magical horses of Rhesus (Il. 10.436-437). Therefore, Odysseus and Diomedes, who are linked with horses themselves, ${ }^{86}$ move further out to fetch

82 On the freedom to accept the supplication, see Naiden 2006, 105-170. However, it seems almost as if they killed him before he could act as official supplicant in order to avoid the wrath of the gods.

83 For the fairytale structure of the Odyssey, esp. in the adventures, see Radermacher 1915; Hölscher 1988; Renger 2006, 200-277.

84 See Propp $1968^{2}$; see also Davies 2005, esp. 30. For the application of Propp's approach in Greek myth, see also Burkert 1979.

85 See Bierl 2009a.

86 For Odysseus and the horse, see Hölscher 1988, 61-63; according to S. E. M. 1.267 , Odysseus is transformed into a horse in the end of his life; for the won- 
them. In other words, in the end the originally strategic plan is surprisingly turned into a quest and theft of horses.

The Greek heroes commit a massacre by brutally killing Rhesus and his comrades, even though they could have stolen the horses from their sleeping enemies. The Doloneia only tangentially embeds the standard myth and other narrative traditions of the Epic Cycle. According to these, Rhesus is a mighty latecomer who could become dangerous to the Achaeans or might even be invincible, as soon as his horses have drunk from the waters of the Scamander. ${ }^{87}$ Instead, Iliad 10 adapts these versions to the situation of the mystical quest in the realm of death and night. In the epic emplotment, the Greeks want to overcome darkness and lack of energy. Already the wake-up calls had an energizing effect and entailed forward action. The Greek pair trick the single, barbarian enemy, who himself was eager to obtain Achilles' magical horses and chariot (Il. 10.305-306, 319-323, 401-402), ${ }^{88}$ and, in turn, succeed in bringing back two magical horses from the Trojans. ${ }^{89}$

In a nutshell, the Iliad has a wonder- and folktale substratum of otherworldly horses and related issues. This motif especially applies to Achilles' divine horses, one of them, Xanthus, can even speak (Il. 19.408-417). The improbability of this occurrence is weakend by the remark that Hera gave the horse the ability to speak (Il. 19.407). The Erinyes then intervene and stop him from uttering further words (Il. 19.418). ${ }^{90}$ Comparative research supports the hypothesis that the

drous horse in Propp's structural approach of the wondertale, see his functions

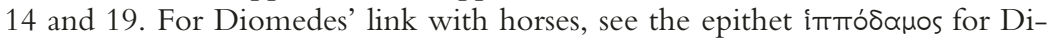
omedes (Il. 5.415, 781, 849; 7.404; 8.194; 9.51, 711) and his father Tydeus (Il. 4.370), and Shewan 1911, 176; with respect to the merging of his Thracian counterpart, see Davies 2005, 34. For the Thracian Diomedes as death daimon, see Fontenrose 1959, 345.

87 See schol. ad Il. 10.435, T, A, and B, and Fenik 1964, 5-8; Dué/Ebbott 2010, 89-106.

88 Since Dolon is so keen on these precious objects, he supposedly focuses on Rhesus' chariot and horses.

89 Not the chariot: When Diomedes considers seizing the chariot (Il. 10.503505), Athena intervenes and calls on him to return quickly (Il. 10.507-511).

90 Following Wilamowitz 1900, 563-565 (= Kl. Schr. IV, 140-142) and Malten 1914, 203, Johnston (1992) interprets the passage in a neoanalytical manner as an allusion to a scene between Adrastus and his horse Areion who, inspired by the Erinyes, warned his master, since one of the Furies is the mother of the horse. Other critics claim that by announcing his death with human speech, Xanthus transgressed against the cosmic order, for whose observance the Furies 
horses, as chthonic and infernal animals which are endowed with prophetic speech and linked to water, are again linked to shamanic concepts in which the horse serves as the medium for the shaman on his journey to the otherworld. ${ }^{91}$ The fierce battle scene of Book 21 takes place by and with the river Xanthus which, bearing the same name as Achilles' horse, is both identical to Scamander and marked as a metonymical boundary separating the world of the living from Hades. Already at the end of Book 20, Achilles is emblematized as an infernal fighter whose horses trampled the bodies and shields while the wheels of his chariot and feet of the wild horses splashed everything with dreadful blood (Il. 20.490-503). At the beginning of Iliad 21, Achilles drives half of the masses of his enemies into the Scamander, which is associated with the underworld (Il.21.1-16). The whirling, murmuring waters are filled with a mix of men and horses (Il.21.16). Then, he leaves his spear leaning against the tamarisks (Il.21.18) - a marked reference back to the Doloneia (10.465-466), steps in the river and fights only with his sword (Il. 21.19: póoravov). ${ }^{92}$

After all, the entire rampage (Il. 21.1-384) is symbolically linked to descending into the realm of death. ${ }^{93}$ First, Achilles kills Lycaon (Il. 21.33-135), who recalls the eponymous hero of the cannibalistic Lycaea, throws him into the floods of the Scamander and triumphantly cries out that that there will be no rescue, although Lycaon has drowned horses still living in its eddies (Il. 21.132). Usually the chthonic horses are sacrificed to the dead or simply for atonement. ${ }^{94}$ The massacre of

are responsible (references in Johnston 1992, 91 n. 16). Both horses weep, too, when they hear about Patroclus' death (Il. 17.426-428).

91 For shamanic motifs and the connections between death, rock, water, winds, supernatural speech and horses, see Milićević Bradač 2003. For chthonic associations of the horse, see Malten 1914 and Davies 2005, 33.

92 Later on, when Hephaestus sets the river on fire, the tamarisks near the river burn (Il. 21.350). For religious associations of the tamarisk, plant of the marshland, with divination and prophecy, see Wathelet 1989, 221 n. 35; see also Dué/Ebbott 2010, 359 ad Il.10.466-468.

93 Mackie 1999 interprets Book 21 as a symbolic katabasis; according to him, Achilles " "descends" onto the battlefield" (500), which is "a kind of hell" (499); he associates the burning river with the infernal river Pyriphlegethon (487, 497-498).

94 For death associations of the horse, see Malten 1914; for sacrifices, particularly of white horses, to the dead and for the purpose of atonement, see Stengel 1910, 155-162, esp. 161. Briefly before, Achilles selects twelve Trojans as human sacrifice for the atonement of Patroclus' death (21.27-32); they will 
the Trojans as a perverted, human sacrifice performed in atonement for Patroclus is a dreadful offense against the river; therefore, Xanthus fights back. When Achilles is in real danger, Poseidon reassures him, like the soul arriving in the underworld, not to be afraid or anxious (Il. 21.288:

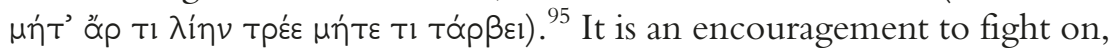
and in extreme distress, Hephaestus helps him with cosmic fire to fight against the river of Hades, which is set on fire like the river Pyriphlegethon. ${ }^{96}$ Fenik has demonstrated that Rhesus resembles Achilles in many respects. Both have divine or second-rank divine mothers, are reared by nymphs and destined to die if they fight at Troy. And they possess splendid horses and armor, are mourned by their mothers, and receive a special exemption after death. Both even have characteristics analogous to Memnon, whose mother is Eos. ${ }^{97}$

In sum, the story, with its frequent reversals, incorporates all sorts of combinations and variations of similar motifs. Achilles is reflected in Rhesus, and all of the intricacy conveys a symbolic underpinning of death and light. Like other magical horses such as Areion, which often have identical names, the horses of both kings are linked with the Erinys, a Harpy, water, the winds that snatch people away to Hades, prophecy or musical inspiration. It is not by chance that Rhesus' mother is a Muse. Sometimes miraculous horses are associated with rocks from where water rushes and under which dreams are to found (Alcman fr. 1.45-49). In short, they reside in the otherworld of inspiration. ${ }^{98}$ According to $\mathrm{Od} .24 .11-12$, the district of dreams is close to

be burnt on Patroclus pyre (23.175-182) along with other animals and four horses $(23.171-172)$. The twelve Trojan youths might be linked with the twelve Thracians brutally killed around Rhesus; see Bernacchia 1990, $46 \mathrm{n}$. 13 and now also Dué/Ebbott 2010, 362 ad 10.488; Schnapp-Gourbeillon 1981, $116=1982$, 61 associates them, however, with the twelve Trojans warriors close to Patroclus' body who were killed when Achilles appeared and cried out three times (18.228-231). Gernet 1936, 200 with n. 3 connects the twelve Thracians to the "Monsters of the Twelve Days", a period of exception and carnival (195) when in modern Greece the wolf-demons Kallikantzaroi, linked to werewolves, roam the streets. For the connection of the Kallikantzaroi with horses and shamanism, see Bierl 2009, 28 n. 52.

95 The usual tharsei is missing here.

96 For тupi $\phi \lambda \varepsilon \gamma \varepsilon \dot{\vartheta}$ ovtı in Il. 21.358 and the Pyriphlegethon, see Mackie 1999, 497-498.

97 Fenik 1964, 30-37 who relates the features to the Cyclic tradition.

98 In the famous Louvre-Partheneion by Alcman, the maidens of the chorus compare one of the outstanding and beautiful female chorus-leaders to a horse 
other boundaries to the underworld, such as Oceanus, the White Rock and the gates of the sun. In the Cyclic myth of the oracle version transmitted by the scholium in the manuscript Venetus A to Il. 10.435, Rhesus' horses are associated with water: if Rhesus - usually himself son of the Thracian river Strymon, but here son of a mortal Eioneus - and his horses drink from the river Scamander, he will be invincible. Drinking water when entering the underworld is a common distinctive feature on many gold leaves (OF 474-484).

The motif entails another reversal of the real story, since as soon as Rhesus tastes the waters of Mnemmosune, the mother of the Muses, he is part of the underworld and 'invincible' in this realm, since Troy is a kind of otherworld. As a Thracian, he is associated with Orpheus, another seer, singer and son of a Muse who is also connected with the sun. ${ }^{99}$ Therefore, Rhesus personifies the prophetic voice - that is, the oracle itself - and even a metapoetic instance, the source of this poetic episode. As the object of the song, 'he will be unconquerable forever'

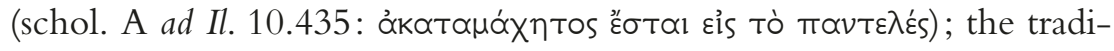
tion about Rhesus cannot be defeated in an agōn and is thus unforgettable, that is, eternal and "op over, Rhesus is described as being immersed in a world of dreams: he is dreaming, probably of Diomedes himself when he is brutally killed (Il. 10.495-497). ${ }^{100}$ In other multiform versions of the myth, especially in Rhesus 962-973, it is reported that he was granted immortality, and in the Cyclic Aethiopis, Achilles was brought to the isle of Leuke. ${ }^{101}$

After their death, Rhesus, Memnon, and Achilles are given a special exemption from mortal destiny through the intervention of their mothers, and thus live on in otherworldly territory. ${ }^{102}$ The myth is amalga-

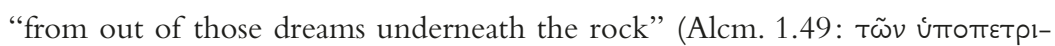

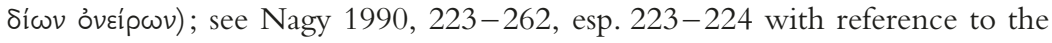
scholia A.

99 The scholia A, B and T ad Il. 10.435 state that Rhesus' mother is Euterpe; at the bottom of the folio of A is a list of other singers who are descended from Muses, starting with Orpheus, son of Calliope or Cleio. After Linus the Thracian Rhesus is third, here also linked with Terpsichore. For Orpheus' love and veneration of the sun, see the sources given by OF 536-545 Bernabé. See also Bierl 2009 a with n. 85 and 86. For Rhesus as a "prophet of Bacchus" in an OrphicDionysiac context, see Rhesus 972 and Bernacchia 1990, 52.

100 Fenik 1964, 50-51.

101 See the White Rock and above n. 98.

102 Fenik 1964, 30-31. 
mated to a new variant that blends death with afterlife experience. ${ }^{103}$ Furthermore, another Diomedes is somehow merged into the story about the Thracian hero killed by Diomedes, son of Tydeus: I mean the Thracian Diomedes, son of Ares and Cyrene and king of the Thracian Bistonians who fed his mares of similar names, Podargos, Lampon, Xanthus and Dinus, the human flesh of all arriving strangers. ${ }^{104}$

When the Greeks are in great peril, the narrator clearly sides with them. ${ }^{105}$ The pro-Achaean exception from the rule of neutrality is caused by the situation. In the end, it becomes obvious that the new goal of the entire mission has shifted to the heroic theft of the wondrous horses that are thematically related to the sun. Nestor, the hero who by etymology "brings back to life and light", ${ }^{106}$ is the appropriate figure to send Diomedes and Odysseus out and to receive them afterwards. The symbolic descent to death comes to an end by bringing the horses standing for light and the sun. Nestor wonders at these mares that are, according to him, "terribly similar to the rays of sun" (Il. 10.547: aivẽs

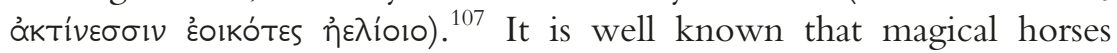
that bear names designating beaming and shining are metaphors for the sun itself. Sometimes only two horses which are white, ${ }^{108}$ but in most cases four horses with different names, ${ }^{109}$ draw the wagon of $\mathrm{He}-$ lios. At the westernmost edge of the earth, he is put in a boat, often de-

103 On images of Rhesus on three Apulian vases (Naples, Museo Archeologico, H.2910; Staatliche Museen zu Berlin, Antikensammlung, Inv. 1984.39 and V.I.3157) of sepulchral function with the focus on the myth of his death and afterlife associations, see Giuliani 1996. On these images, the white horses are also very prominent.

104 See Bethe 1903, 817 and Davies 2005, 34.

105 See Stoevesandt 2004, 156-159, esp. 158-159; the Doloneia lacks the usual balance; see also Ranke 1881, 79; Shewan 1911, 7-8.

106 Frame 1978, 96-115 and 2009, 23-102 argues that Nestor and his brother Periclymenus as horsemen are equivalent to the Dioscouroi and the Vedic Asvina, the twin horsemen and saviors. The Doloneia can thus be read as a story of how Nestor sets the return to life and light in motion after a long night symbolizing death. With his noos, Nestor awakens thought and brings back consciousness, ibid. 94.

107 Only Wathelet 1989, 226-230 and Dué/Ebbott 2010, 375 ad Il.10.547 refer briefly to sun imagery.

108 See e.g. the lekythos in Athens, Polythechnicon collection Reg. No. 3506; see Savignoni 1899. For the sun as white horse, see Malten 1914, 251.

109 Ov. Met. 2.153-154: Pyrois, Eous, Aethon, and Phlegon; Eumelos test. 12 Bernabé in Hygin. Fab. 183 and epic Titanomachia fr. 7 Bernabé: Eous = Eoios, Aethops, Bronte, and Sterope. Other names are: Lampos and Actaeon. 
scribed as cup or bed, and is carried around Oceanus, from the place where he sets to the place where he rises. ${ }^{110}$ Lampos and Phaethon, also an ornamental epithet for Helios (Il. 11.735) associated with the notion of brightness, draw the chariot of Eos (Od.23.246), who precedes Helios. In connection with the myths related to the sun and light, Gregory Nagy has shown that we can find a pattern of abductions of male figures by sun-daughters like Eos and Aphrodite. Like a Harpy or gusty winds, which are associated with the horses as well (see Il. 16.149-151), they snatch away beautiful youths as the prey of female desire. The death of the young male lovers is followed by their preservation underneath the earth, once more a notion of the rising sun. Rhesus, in a way, is analogous to figures like Cleitus, Tithonus, Phaethon or Clymenus. Like Achilles or Memnon, he has an afterlife in the underworld. In his unconscious state of sleep and dreaming, he is also part of lethe; forgetfulness is the state of death. ${ }^{111}$

The Doloneia thus combines all elements in the multiform of myth. Phaethon is also a hypostasis of Helios himself, and in the same way, Rhesus' horses are hypostatic figures for Rhesus and the sun. He is snatched away with his horses into the realm of the Trojan battlefield, of symbolic death, dreams and forgetfulness. Then, Rhesus is killed, and the brutal deed only affirms his status. Afterwards, his horses are again abducted (instead of himself) and brought to the other side for preservation in order to bring light. In the course of this night, the crisis is so severe that both parties, on a symbolic level, want to interfere with the horses of the sun. Dolon is eager to receive Achilles' team and chariot that symbolically represent the same contents of light and life, yet in the end, Odysseus and Diomedes carry off Rhesus' team, after having killed Rhesus' twelve associates, maybe representing the twelve months,

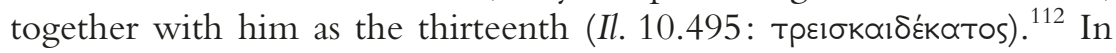
the Odyssey, Odysseus himself is closely connected to solar signs and mythic elements linked to the sun. ${ }^{113}$ Therefore, it is not by chance that he has been chosen to perform this action. Both Diomedes and

110 See Stesichorus 185 PMG; Mimnermus fr. 12 West; Pherecydes 3 F 18a FGrHist.

111 See Nagy 1990, 234-255. For Harpies, winds, rape, and death, see Vermeule 1979, 145-178, esp. 168-171.

112 See Dué/Ebbott 2010, 363 ad Il.10.495 for the "completing or capping aspect" of the number thirteen, perhaps "related to the lunar calendar, the year coming round in the thirteenth moon".

113 See e.g. Frame 1978, 34-80. 
Odysseus act like Greek shamans, goêtes or magoi, who fetch some supernatural power and solar light from the realm of death. Their return is then secured by the sêma (signpost and tomb) of the bloody armor on the tree. As we have seen, the sēma is a funerary remnant of an atavistic hunting ritual. ${ }^{114}$ By practicing the black hunt, mêtis, and murder, they regain life. In the end, their return from a symbolic katabasis and their reintegration into the Greek army are ritually acted out. In another rite de passage, they perform the ritual of washing, first in the sea, then in a bath tub, a double cleansing from the violent act and visit to death (Il. 10.572-576). ${ }^{115}$ Finally, at breakfast they perform a wine libation for Athena who has helped them (Il. 10.578-579). In this sacrificial scene, they must have also given Dolon's bloody spoils to Athena, which Odysseus had laid down by the stern of the ship (Il. 10.570571).

After emphasizing solar images, at the very beginning of Book 11 (lines $1-2)$ the poem tells how Eos gets up. After the extended night, which was close to death, the sun rises and shines for the Greek side again. Zeus sends them Eris, the personification of agonistic power, to prevail in battle $(11.3-12)$ - at least for some time. Agamemnon now calls the troops to battle and puts on his usual, contemporary armament that has nothing to do with the prehistoric ones in Book 10 - for this reason, it is described in detail (Il. 11.16-45) - and finally performs his aristeia. From his total collapse in Iliad 9 and 10, he is invigorated at the beginning of Book 11, and suddenly he is able to lead his army. ${ }^{116}$ Death was transformed to life, night to light and desperation to hope.

114 See above n. 64.

115 Often the doublet was felt as poorly motivated; see Ranke 1881, 37-38; Ameis/Hentze 1888, 45 ad 576-577; Leaf 1900, 463 ad Il.10.576; Shewan 1911, 181-182. For a poetics of the bath, see Grethlein 2007; he subsumes this passage under the category of the bath of the hero returning from battle (27); yet it also clearly highlights the critical transition from death to life: see Dué/Ebbott 2010, 378-381 ad Il.10.576.

116 Without regarding the symbolic underpinnings, see already e.g. Bäumlein 1856, 425-426; Kiene 1864, 91; Shewan 1911, 143; see also Ameis/Hentze 1888, 11; see also Cirio 1998, 27. She sides with the naturalistic interpretations, too; see ibid. $50-52$, esp. 52 . 


\section{Horses and Solar Light as Key Motifs: Links with the Iliad}

Particularly in regard to the horses that symbolically underscore the transition, the Doloneia is well embedded in the Iliad. Beginning with Book 8 , the military turning point of these developments, the preoccupation with important horses that carry solar associations is noticeable. ${ }^{117}$ I argue that Nestor is the key figure for establishing the link. He is called by the formulaic epithet hippota; thus, he is the horseman par excellence, and the one who is by name responsible for return. According to Douglas Frame, Nestor is based on the Indo-European myth of twins who stand in a solar context. His name is derived from the reconstructed root *nasati-ya, "he who brings back to light and to life", and refers to the Indo-Iranian figure Nasatya. In the widespread saga of twins, one brother is immortal and active, associated with horses, and brings his mortal, less vital brother, linked to cattle, back to life. Frame argues that Nestor unites both aspects, and that this element is fundamental for his myth. He contends further that the root is connected to noos: as a savior figure, Nestor instigates consciousness and awakens thought, and, in daily rhythm, he sets the returning sun in motion. ${ }^{118}$

The aetiological story (Il. 11.670-762) of how he, after starting out with cattle raids, took over the position of his brother Periclymenus and became a horseman follows in the next book after the Doloneia. ${ }^{119}$ And immediately before, in Book 8, the focus is on Nestor's close relation to Diomedes. Odysseus and Diomedes constitute another pair, not of twins, but of comrades who are particularly eligible for this sort of night raid accomplished with ßin and $\mu \tilde{\eta}$ тıs. ${ }^{120}$ Because in the Iliad Nestor belongs to the previous generation, he is too old to fulfill his function alone. Therefore, in the Doloneia, Diomedes and Odysseus serve as his substitutes to bring back light and life from darkness and death. They

117 For the role of horses in the Iliad in general, see Delebecque 1951, esp. $241-$ 244; Schnapp-Gourbeillon 1981, 169-178. For the relevance of the horse in modern oral traditions of Balkan and Central Asiatic epics, see Lord 1991, $221-234$, esp. $221-224$.

118 See Frame 2009, 9-94, esp. 93-94.

119 For this inset tale in the exchange between Nestor and Patroclus Il. 11.605803, see Frame 2009, 4, 11-12 and 105-130 and Alden 2000, 88-101.

120 Diomedes is paired with Odysseus in similar epic episodes: the drowning of Palamedes; the theft of the Palladion; a night raid in which they wound Polyxena; the capture of Helenus that leads to the recruitment of Philoctetes; see Dué/Ebbott 2010, 33-34, 41-43, 285-286. 
transform $\lambda \eta \eta \vartheta \eta$ and unconsciousness into consciousness. Odysseus as polumetis is prone to taking on the part of $\mu \tilde{\eta} \tau i s$, whereas Diomedes leads them out of the realm of death by committing Bin and murder.

Despite his age, Nestor is still the eye-opener, the instigator who gives counsel and 'awakens' thought. The story embeds these functions in his active part of the detailed wake-up process, the long introductory part or nuktēgersia which has been criticized so much in the past (Il. 10.1-298, esp. 1-202). ${ }^{121}$ Since he belongs to the old generation, he had to be activated by the actual commanders Agamemnon and Menelaus who, in a way, reflect the twin brothers: Agamemnon has to play Nestor's active role, while Menelaus is the one who has to be set in motion. ${ }^{122}$ Therefore, the scene starts with Agamemnon and Nestor meeting with Menelaus, who ironically is doing better than usual this time. However, it is Agamemnon who wakes up Nestor (Il. 10.54-56, 73107) whom he wants to seek out from the very beginning (Il. 10.18) "to see if Nestor with him could work out a plan that would not fail, and one that might drive the evil away from all the Danaans"

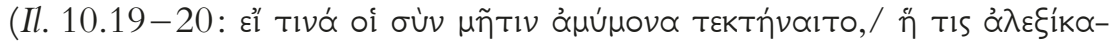

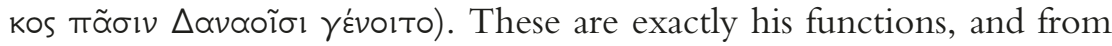
now on it is Nestor who by means of his vóos sets everything in motion. As is typical, Nestor is the first to become aware of the horses' thunder (Il. 10.532-539); his anxiety about Diomedes' and Odysseus' destiny, because he was not able to take care for their vóotos (Athena did so in Il. 10.507-511), is dissolved by their safe arrival. All welcome them, but it is again Nestor who speaks first, immediately questions them about the horses and receives an answer by Odysseus (Il. 10.543-563). Thus, the central episode of bravery in the Doloneia is doubly framed by hippota Nestor, internally in Iliad 10 and externally by episodes in Iliad 8 and 11, and horses, night and light play a significant role in all these Books.

At an early stage of Book 8 , right after the negative outcome of Zeus' balancing the scales (Il. 8.72-74), most of the famous Greek heroes do not venture to continue fighting. But Nestor is the only one to stay because one of his horses is fatally wounded in the head by one of Paris' arrows. Due to this incident, Nestor has to stop and runs into severe trouble, since Hector arrives at this moment with his fast running

121 E.g. Ameis/Hentze 1888, 4-7.

122 Compare Frame 2009, 72 n. 156, 177, 191. In the case of the return from Troy, it is actually the other way around (Od.3.141-147). 
horses (Il. 8.80-90). The old hero of safe return must now be rescued himself. Diomedes becomes aware of his situation and calls on Odysseus to support him in order to achieve a safe return for Nestor. Yet at this point, his usual partner in all sorts of undertakings does not react and runs away toward the camp without taking notice (Il. 8.93-98). Therefore, Diomedes realizes that he must help alone. He addresses Nestor, remarking that his strength is undone by old age, his attendant weak and his horses are slow (Il. 8.103-104).

Diomedes then calls Nestor onto his chariot and urges him to see how agile and fast his Trojan horses are in their flight, which he had won from Aeneas with the help of Sthenelus (Il. 8.105-108; cf. Il. 5.318-327 referring to Il.5.261-273). Nestor takes over the reins of Diomedes' team, and Diomedes now attacks Hector with great success. However, at this point, Zeus intervenes by frightening Diomedes' horses with thunderbolts (Il. 8.133-137). Even against the clear warning of Nestor (Il. 8.139-144), Diomedes ponders three times whether to turn the course of the horses and fight against Hector, who taunted him as a coward (Il. 8.161-166), but three times Zeus sends thunder as a sign of victory for the Trojans (Il. 8.167-171).

Therefore, Hector encourages his troops with a speech to move on against the Greek fortifications. He goes on boasting that they are not worthy of consideration: his horses can easily jump over the ditch (II.8.179) to then reach the Greek ships and burn them down (Il. 8.173-184); and he calls aloud to his horses and adresses Xanthus, Podargos, Lampos and Aethon directly ${ }^{123}$ to repay him for their care so that he might capture Nestor's shield and Diomedes' corselet (Il. 8.184-197). Hector's horses bear the typical names in the divine and heroic context. ${ }^{124}$ Encouraged by the parainesis of Agamemnon, the Greeks try to stop Hector's onslaught. Hera and Athena take pity on the Greeks and want to come to help them despite Zeus' interdiction. In deep anger at this interference, Zeus sends out Iris to announce that he would be determined to stop their horses and even to commit raw violence against both goddesses (Il. 8.397-424). Since in the following Olympian assembly they still feel sorrow for the Achaeans, Zeus gives his first strategic overview (Il. 8.470-476): the next long day, the second battle day in the menis-plot, will be decisive. Hector will not

123 Aristarchus athetizes $\mathrm{Il} .8 .185$ on the grounds that Hector as warrior drives four horses instead of two; see also the duals in 186 and 191; he is followed by West 1998, 234 and Kirk 1990, 312 ad 185, with remarks on the combination of the names taken from different contexts.

124 We recall the names of the horses of Helios, Eos (Phaethon and Lampos, Od. 24.246) or Achilles (Xanthus, Balios, with their mother Podarge, Il. 16.150-151). 
stop until Achilles returns, when the Greeks fight over the body of the dead Patroclus.

This passage provides the basic plot by means of a prolepsis. That said, the sun sets and suddenly dark night comes over the scene, which means salvation for the Greeks in the last moment. The diction is very drastic and is worth citing (Il. 8.485-488):

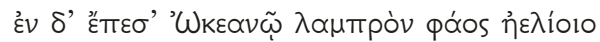

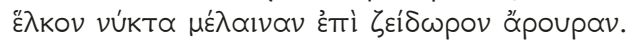

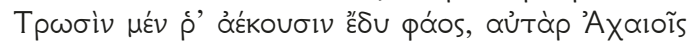

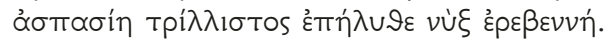

And now the shining light of the sun was dipped in the Ocean trailing black night across the grain-giving land. For the Trojans the daylight sank against their willl, but for the Achaians sweet and thrice-supplicated was the coming on of the dark night.

In reaction to the waning daylight, Hector gives orders now (Il. 8.497541) that the Trojans should obey night, loose their horses and camp outside, and that campfires should give light for the guards. Even in the city, fires and guards should prevent a lokhos when the soldiers are outside (Il. 8.522). Lokhos, ambush, is the decisive link with the Doloneia. At dawn they will attack and awaken their fighting energy (Il. 8.530-531). The Trojans do as their leader said: they camp outside and burn hecatombs, but the gods do not accept their sacrifice because Ilium has become an object of hate for them (Il. 8.545-552). There are a thousand bonfires, and the Trojans sit in groups of fifty around each (Il. 8.562-563), and the narrator tells that these bonfires provide light like stars around the moon (Il. 8.555). The Book ends with a focus on the horses that wait for the next morning (Il. 8.564-565):

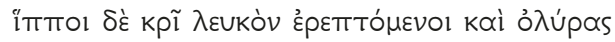

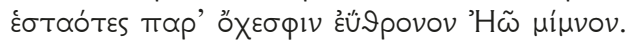

And standing each beside his chariot, champing white barley and oats, the horses waited for the dawn to mount to her high place.

The burning fires are a severe threat to the Greeks' safety in the dark. There is a danger that the Trojans might even attack. Nestor summarizes the critical situation as follows: many fires are burning, and this night will destroy or save the Greeks (Il.9.77-78). Also, in the beginning of Iliad 10, Agamemnon is worried as he looks at the "many bonfires" (Il. 10.12) that the Trojans might use the dim light to plan a stratagem based on $\mu \tilde{\eta}$ Tıs. Agamemnon's offending offer for compensation to 
Achilles includes twelve wonderful horses (Il. 9.123-124, 265-266). Yet Achilles rejects all material goods because his wondrous horses are, one could surmise, enough for him.

After Book 10, Agamemnon puts on a regular suit of armor (Il. 11.16-45) instead of animal furs, which served as the marker of atavistic regression. With new energy, the Achaeans and their horses jump over the ditch and attack the enemy. Odysseus and Diomedes now fight side by side in a heroic battle by day until Diomedes is hit by Paris' arrow. Agamemnon and Odysseus are soon wounded, too. Finally, Machaon, the famous doctor, is hit again by Paris' arrow, and Nestor has to take him out of the battle to his tent, where he cures him with a magical drink, a kukeōn, from his famous cup (Il. 11.624-641). At this point, in a first peripeteia of the mennis-plot, Achilles gives orders to Patroclus to visit Nestor to ask him who is the wounded man. In order to encourage and 'awaken' Patroclus, Nestor tells him the aforementioned episode of the raid of cattle in Elis (Il. 11.670-707). Aside from other animals, he swapped 150 horses (Il. 11.680-681) in a night maneuver. When the Elians sought revenge and attacked Pylos, Athene appeared during night to encourage the Pylians to fight back (Il. 11.714-716). In this battle, the young Nestor became a warrior and a horseman for the first time (Il. 11.707-761). ${ }^{125}$ First, he killed Moulius, the 'battle' (appa-

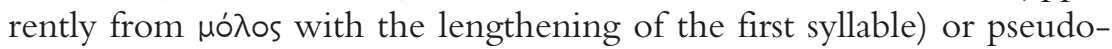
etymologically the 'mule', ${ }^{126}$ and took his horses (Il. 11.738-739), the beginning of an energetic action and aristeia. Under Nestor's command, the Pylians waged war until they led the horses to Bouprasion (Il. 11.756) where he once lost only the chariot race in the funeral games for king Amarynceus to the Molione, the sons of Actor and Epeian twins (Il. 23.638-642), before he had become the horseman. ${ }^{127}$

125 See Frame 2009, 105-111.

126 For the first and obvious linguistic explanation, see Hainsworth 1993, 303 ad Il.11.738 and 181 ad Il.10.269. However, in this passage we find associations with mules and horses, too. Nestor's question to Agamemnon whether he comes to look for one of his mules or friends (Il. 10.84) perhaps has to be seen in this context of motifs as well. Since critics did not have the association with the key-motif of the horses in mind, the verse seemed to be odd already to the Alexandrians. For a defense in biotic terms, see Shewan 1911, 221-222; Klingner 1940, 360 n. 3; Cirio 1998, 117 ad Il.10.84.

127 See Frame 2009, 131-138. "Like a dark whirlwind" (Il. 11.747), Nestor would have almost killed Cteatus and Eurytus in his first aristeia, if their real father Poseidon had not intervened (Il. 11.751-752). For the connection with the twin myth and the Molione's mention in Il. 23.638-642, see Hainsworth 1993, 304 
I have already noted the associations between Memnon, Rhesus and Achilles. Through splendid, supernatural horses and brilliant armor they are linked with light and the sun. ${ }^{128}$ It has become clear by now that, despite all its realism, the Iliad is informed by a folktale substratum. How unrealistic Achilles' horses are becomes evident at the end of Book 19 where one of them, Xanthus, is able to talk and foretells his imminent fate to Achilles (Il. 19.408-417) who in his new, splendid armor resembles Hyperion (Il. 19.398). When Achilles reappeared without armor at the ditch, he is associated with the brilliance of the rays of the sun in this kind of epiphany (Il. 18.203-214). After all, he is the direct opponent of Apollo, the brilliant associate of Helios, whereas in ritual and cult they are linked with each other in antagonism. ${ }^{129}$ Both Helios and Hyperion possess teams of horses, too. The supernatural nature of Achilles' horses is apparent as well by the fact that they weep when they receive the notice of Patroclus' death, and in their mourning, they cannot be moved to the battlefield again (Il. 17.426-440). Thus, Zeus pities them and promises that Hector will not capture them, and provides them with new energy to bring Automedon back to the ships (Il. 17.441-455). Finally, Hector notices Achilles' horses (Il. 17.485486) and wants to catch them with Aeneas (Il. 17.485-506). However, they will not succeed.

After all, by taking the horses of Rhesus, a sort of counter-Achilles, the Greeks bring the power of life, light and energy to their side. Together with Achilles' horses, now they have four magical mares which are much more powerful than Hector's team of four. Rhesus' horses are so otherworldly and special that they are not used any more in normal battle or in the race of Book 23. ${ }^{130}$ In conclusion, the plot of Iliad 10 is based on a folktale motif. By stealing Rhesus' horses and killing

ad Il.11.750 and Frame 2009, 110-113. When Poseidon, the god of the horses who is closely linked with Nestor, sees the Greeks again hard-pressed and discouraged at the beginning of Iliad 13, he prepares his mares in the stables of Aegae so that he can ride to their aid. The passage emphasizes the golden and shining nature of Poseidon's palace, two horses and armament (Il. 13.20-38), as the god with his chariot brings, to some extent, light to the Achaeans once more.

128 See Fenik 1964, 34-37.

129 See Nagy 1979, 142-144.

130 That is the reason why they are not referred to anymore, especially not in Book 23 - a fact criticized again and again: e. g. Leaf 1900, 423 and West 2001, 10; see also the reference in Cirio 1998, 13. Again with a naturalistic explanation, see Shewan 1911, 179-180. 
their owner, the Achaeans fetch the sun from the realm of death, and possess the light and energy to go on fighting the next day. Furthermore, in liquidating the barbarian musical hero, the Greeks appropriate his splendor and kleos, and the tradition succeeds in incorporating other rhapsodic and mythic traditions.

\section{Conclusion}

Using a holistic and innovative methodology, I have attempted to show that the Doloneia is not a later insertion, but a genuine, organic and necessary part of the Iliad. The epic gradually grew from smaller poems into its monumental size under the influence of Panhellenism and under specific agonistic conditions; it was fixed only later, probably under Peisistratus in Athens. Thus, the Doloneia is not a later addition, but in this perspective, it is part of the tradition. Its unusual distinctive features at first glance can be explained by its narrative function and subgenre. Most of all, Iliad 10 constitutes a diachronic regression into atavistic times and is linked with the perspective of ambush, death, night, and the 'Other'. Therefore, it is neither younger nor older than the rest of the heroic poem, but only refers to older cultural models and narrative modes.

Its narrative function is to symbolically underscore the critical transition from the first short battle day of the menis-plot to the decisive and long second one, from darkness to light, from depression to new confidence, and from death to life. By means of a mythic and ritual poetics, and through inversions, combination and variation of certain patterns, the Doloneia symbolically gives prominence to the crisis and its overcoming. Moreover, by drawing on primordial cultural signs and other forms of storytelling, the tradition succeeds in emotionally engaging the audience and in creating pathos. Far from being a late accretion to be athetized, this song is a narrative nucleus of the Iliad. By hearkening back to a fairytale structure and folklore ideas, Book 10 is the emotional place where the course of the plot is made noticeable. In carrying off the magical horses from the 'Other', the Achaeans regain light and new strength to go on fighting. This momentum leads to the Patrocleia and to the return of Achilles. Shortly before the middle, it emotionally prepares the listener for the peripeteia. In these terms, the victory of the Greeks would be based on an underlying layer of folktale motifs: the Greeks are now in possession of Rhesus' wondrous horses and keep 
the ones of Achilles. The sun, light and energy are coming back to them after the terrible crisis and the close defeat in Book 8. This near-death experience and horror can be overcome by sending a representative group of two heroes to get information and occult power in the dark battlefield, a symbolic katabasis to death.

Unitarians and neo-unitarians have argued that the symmetrical composition of the Iliad speaks for the hypothesis that one poet had an ingenious plan in mind and wrote down the poem. In such a sophisticated design, they assume it was arranged in complementary books, such as Books 1 and 24, 2 and 23, 3 and 22, 5 and 21 and so on, in a semicircle with Book 15 - Patroclus' departure - as its apex, and around it, in a wider curve, they group the divine action. Book 4 with the epipōtesis does not have a counterpart and is seen just as the direct aftermath of the duel between Paris and Menelaus. ${ }^{131}$ Surprisingly, the unitarians almost unanimously do not consider Iliad 10 as Homeric and make little effort to refute its spuriousness; ${ }^{132}$ they claim that an indication of the inauthenticity could be the fact that it does not have a place in such a geometric scheme. ${ }^{133}$ On the contrary, I would argue that the Doloneia does not fit in the geometric form deliberately because it functions as a joint almost in the middle. Not being part of the symmetry serves to highlight its specific otherness, which was also shown in several other respects, such as its diachronic shift in time or the association with death. On the other hand, a geometric structure does not necessarily imply the intentional composition process in written form by a planning poet, but can also be explained with an evolutionary model of oral composition in performance and gradual textualization of a poem that grows into monumental size under Panhellenic influences. Due to changing agonistic circumstances, first at the Panionia then at the Athenian Panathenaea with the relay practice of rhapsodes, the Iliad gradually sorted out all discrepancies and inconsistencies. In the process of composition in performance, the epic poem can be extended by variation and combination as well as by embedding other traditions and patterns. In the

131 I still possess a handout by Prof. Uvo Hölscher prepared for a lecture-class on Homer, which he gave in Munich in 1981. I could not find from where he took it. For a similar argument for a geometric form, see e.g. Whitman 1958, 249-284 and the scheme at the end, also, however, from the view of oral poetry, with uncertainty about whether the Doloneia is genuine or not (esp. 283-284).

132 See e.g. Schadewaldt 1938, 142 n. 4 and Reinhardt 1961, 243-250.

133 See Whitman 1958, 283-284. 
course of numerous performances in the city of Athens, which was interested in fixing a transcript to a script, every detail was gradually fitted into an all-embracing and symmetrical overall structure and design.

The unique Book 10 serves as a symbolic marker of the critical transition in the poem, and this function can be emphasized by the fact that it stands alone in the structure of otherwise complementary books. The Doloneia is neither inauthentic, nor must it be rejected as a later addition. Rather, it is part of the multiform tradition and was gradually incorporated in the act of textualization. After all, not modern aesthetic criteria, but the effect of an organic and emotionally involving epic poem on the audience in an oral performance is the decisive factor for judging the relevance of the Doloneia. 